\title{
Analyzing Three Decades of Philanthropic Giving to U.S. Higher Education (1988-2018)
}

\section{Genevieve G. Shaker}

Indiana University Lilly Family School of Philanthropy at IUPUI

\section{Victor M. H. Borden}

Indiana University Bloomington School of Education

This investigation explores trends in U.S. higher education philanthropy across 30 years, exploring giving by donor type, the purposes of the contributions, and institutionaltype variation in philanthropy. We used a longitudinal national sample (1988-2018) of approximately 400 public and private institutions from the Voluntary Support of Education (VSE) survey. In the sample of mostly 4-year institutions, giving increased by an inflation-adjusted average of $3.6 \%$ annually and $175 \%$ overall, from $\$ 9.1$ billion to $\$ 25.1$ billion (2018 dollars). All donor types gave more dollars, gifts supported a broad range of purposes, and all institutional types benefited. Four notable trends include: an increase in the proportion of donations from organizations, and especially foundations,

Genevieve G. Sha ker, Ph.D. is associate professor of philanthropic studies in the Indiana University Lilly Family School of Philanthropy at IUPUI. She was an advancement officer for 20 years, most recently as associate dean for development and external affairs for the Indiana University School of Liberal Arts. Professor Shaker's research focuses on fundraising and fundraisers; higher education advancement; philanthropy in the workplace; and philanthropy, public good, and faculty work. She is a fellow of the TIAA Institute and was recognized nationally as the Association of Fundraising Professionals' Emerging Scholar.

Victor M. H. Borden, Ph.D. is professor of higher education in the Indiana University Bloomington School of Education, where he also directs the Carnegie Classification of Institutions of Higher Education. Previously, he directed a campus and the universitywide institutional research offices at Indiana University. Dr. Borden's general area of scholarship is on using research and analysis for planning, evaluating and improving higher education institutions and programs. Dr. Borden was a Fulbright Specialist in South Africa and is an active contributor to several professional associations, most notably, the Association for Institutional Research, of which he is a Past President. 
rather than individuals; an early shift in funding toward capitallendowment purposes but then back to current operations since 1998; designation of a larger proportion of funds for restricted, rather than unrestricted, purposes; and a higher proportion of dollars contributed to public, as compared to private institutions. Within sector trends reveal that increased giving to public institutions partly accounts for the rising proportions of both organizational donations and donations for current operations purposes. This study fills gaps in the scholarly literature about higher education philanthropy and provides information for institutional leaders to benchmark fundraising trends and prepare for the future.

Keywords: higher education philanthropy, higher education fundraising, Voluntary Support of Education (VSE) survey

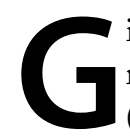
iving to education (and primarily higher education) is second only to religious giving as the largest recipient of donations in the United States (Giving USA Foundation, 2019). More gifts of $\$ 1$ million or greater (48\% of the total) went to higher education than any other purpose between 2000 and 2012 (Indiana University Lilly Family School of Philanthropy, 2013). Individual and organizational donors gave $\$ 46.7$ billion to higher education in 2018 - an increase of $7.2 \%$ (or $4.6 \%$ inflation adjusted) from the prior year, spanning donor types and broad purposes (Council for Advancement and Support of Education [CASE], 2019a). Public and private fundraising powerhouses have fielded successful campaigns with once-thought-impossible multi-billion-dollar goals-and have achieved their objectives (Seltzer, 2017). Mega gifts and groundbreaking institutional gifts are given generously, inviting increased scrutiny of how large gifts are used (Bloomberg, 2018; Scutari, 2018a; 2018b).

Despite these signs of fiscal health, there are some signs of distress. Six in 10 Americans say that "higher ed is heading in the wrong direction," with tuition costs and employment skills as the leading areas of concern (Brown, 2018). Americans' views of higher education's contributions to society and individual success vary by political party, race/ethnicity, and whether or not they themselves hold a college degree, showing that postsecondary education's value has become a contentious topic (Brown, 2018; Drezner, Pizmony-Levy, \& Pallas, 2018). Colleges, universities, and their top donors face critiques that philanthropy is not doing enough for needy students (Foster, 2016; Satija, 2018). Internal and external stakeholders are concerned about the influence of big donors on campuses, compromising institutional independence (Hunt, 2018; Scutari, 2019; Valbrun, 2018). Some are questioning the morality of donors' continued support of the most highly endowed institutions (Jaschik, 2017) and the spending policies governing endowments (The Chronicle of Higher Education, 2018; Kim, 2017; Thelin \& Trollinger, 2014). Some are also doubtful about the specific purposes that institutional endowments serve (Oxtoby, 2015). 
Governmental policy and philanthropic trends are additional factors to consider in relation to higher education philanthropy. Congress' concern about endowment spending rates is evident in the 2017 federal tax law that taxes the endowments of some private institutions (Seltzer, 2018a). The consequences of American tax policy changes to the individual exemption are yet to be fully determined but could lead to dramatic declines in gifts (Delaney $\&$ Thompson, 2019; Rooney, 2018). Indeed, in 2018, overall giving increased by $7 \%$, but in inflation-adjusted dollars there was a decline of $1.7 \%$ from the prior year (Giving USA Foundation, 2019). Giving to all educational purposes was down in 2018 by $3.7 \%$ in the Giving USA analysis, diverging from the Voluntary Support of Education (VSE) survey's higher education analysis (CASE, 2019a). The number of donors is sinking and there are fewer smaller and medium sized gifts (Grimm \& Dietz, 2018; Rooney, 2018). Moreover, there are concerns that the novel coronavirus may cause significant declines in giving to colleges and universities (Bauer-Wolf, 2020).

Higher education institutions use philanthropy to fund all manner of institutional needs and priorities (Drezner, 2011; Thelin \& Trollinger, 2014). There is little research that provides broad perspectives on donor giving to higher education over time and across institutions (Drezner \& Huehls, 2014; Proper $\&$ Caboni, 2014). The majority of the academic research focuses only on parsing the giving of alumni at individual institutions (Drezner, 2011; Drezner \& Huehls, 2014; Field, 2011; Proper \& Caboni, 2014) rather than on more comprehensive examinations of the diversity of donors, institutions, and gift purposes. New, sustained, and broad-based research is needed for practical and scholarly reasons.

The purpose of this study is to provide a descriptive, longitudinal, and national perspective on philanthropic giving to higher education. The research questions focus on examining the purposes donors supported with their gifts, differences in giving among types of donors, and variations in donor giving across institutional types. We examine broad donor trends across capital/ endowment and current operations purposes, focusing additional analysis on current operations restricted giving. The analysis used data from a panel sample of about 400 public and private colleges and universities from the Council for Advancement and Support of Education's (CASE) VSE survey, examining their annual philanthropic donations at ten-year intervals (1988, 1998, 2008, and 2018). The VSE dataset, comprised primarily of 4-year institutions, was supplemented with institutional information from the National Center for Education Statistics (NCES) Integrated Postsecondary Education Data System (IPEDS).

During the three-decade study period, giving increased by an inflationadjusted annual average of $3.6 \%, 175.1 \%$ overall, from $\$ 9.124$ billion to $\$ 25.103$ billion (2018 dollars). All donor types gave more dollars, gifts covered the full range of purposes, and all institutional types benefited. Four notable trends include: an increase in the proportion of donations from organizations, and 
especially foundations, rather than individuals; an early shift in funding toward capital/endowment purposes, but then back to current operations since 1998; designation of a larger proportion of funds for restricted, rather than unrestricted, purposes; and a higher proportion of dollars contributed to public, as compared to private institutions. Within sector trends reveal that increased giving to public institutions partly accounts for the rising proportions of both organizational donations and donations for current operations purposes. These trends likely reflect some of the phenomena mentioned here already such as institutional sophistication and advances in fundraising-particularly among public institutions-(Conley \& Tempel, 2006; Lorin, 2017; Indiana University Lilly Family School of Philanthropy, 2013), growth in foundations (Foundation Center, 2019), rising questions about the outcomes of higher education (Brown, 2018; Drezner et al., 2018), public concerns about endowment purposes and management (The Chronicle of Higher Education, 2018; Kim, 2017; Thelin \& Trollinger, 2014), and others, such as higher education's relative resilience following stock market declines as compared to other nonprofit sectors (CASE, 2019a).

Maintaining philanthropic success in the current era, however, is certainly not a forgone conclusion especially given the unanticipated and confounding challenges confronting postsecondary education such as the 2020 novel coronavirus pandemic. These findings are important for understanding the potential and limitations of fundraising for institutional vitality and for institutional strategic planning that relies on fundraising as a revenue source. This study is intended as a resource for both practitioners and scholars. Consequently, the findings and interpretation are presented together in an analysis meant to connect with broader trends and to illuminate their potential manifestations at the institutional level. The findings are followed by a discussion of the study's limitations and further exploration and illustration of the four key trends as well as opportunities for future research. The study is framed by research about why different populations give to higher education and how philanthropic giving varies across institutions.

\section{DONOR SUPPORT OF HIGHER EDUCATION}

Over the last four centuries, the nature of donor involvement in U. S. higher education has evolved, but philanthropy has been a consistent factor in the formation, operations, and development of numerous institutions and the higher education sector as a whole (Drezner, 2011; Thelin \& Trollinger, 2014). Then and now, donors often gave for specific purposes-from facilities to curriculum to research to scholarships-but also provided funds for institutions to use where the need was greatest. A range of researchers have sought to understand giving behaviors, primarily to determine the most fruitful fundraising strategies (Proper \& Caboni, 2014). 
Most research on giving to higher education examines the personal characteristics and demographics of alumni individuals (Drezner \& Huehls, 2014; Proper \& Caboni, 2014). Variables that have been found to be significant in parsing populations of individual donors include wealth (Brown, Dimmock, Kang \& Weisbenner, 2014; Clotfelter, 2003; Cunningham \& Cochi-Ficano, 2002; Weerts \& Ronca, 2007), age (Grant \& Lindauer, 1986; Lara \& Johnson, 2014), and institutional experiences and sentiments (Caboni, 2010; Drezner, 2011; Leslie \& Ramey, 1988; Mael \& Ashforth, 1992; Simone, 2009; Weerts $\&$ Ronca, 2007). Alumni (and other individuals) may be motivated to give and to give by perceived need, social benefits, and/or educational quality (Brown et al., 2014; Leslie, Drachman, Conrad, \& Ramey, 1983; Leslie \& Ramey, 1988; Taylor \& Martin, 1995; Weerts \& Ronca, 2007) and also by feelings of pressure, guilt, and joy (Andreoni, 1990). Social returns-from inclusion in donor groups and access to institutional privileges-and personal recognition can also drive individuals' philanthropic activities in higher education (Harrison, Mitchell \& Peterson, 1995; Thompson, 2010). A ten-year study of alumni giving to public research universities found no divergence or convergence in levels of giving among institutions (Simone, 2009), suggesting that fundraising among alumni populations rises and falls with some consistency across institutions.

Thus far, large-scale studies have rarely focused on the goals and purposes of individuals' giving to higher education or the broader, institutional or sectoral outcomes of their philanthropic gifts. Aspects of these topics have been explored in smaller qualitative studies (e.g., Cascione, 2003), reports in industry and popular media (e.g., Scutari, 2019; Valbrun, 2018), and some examinations of individual, corporate, and foundation influence on philanthropy generally or particular dimensions of higher education (e.g., Hunt, 2018).

Indeed, research on foundations has tended to attend heavily to giving purposes using historical and evaluative approaches. From historians we know that foundations helped shape the American research university, establish the terms for a comprehensive higher education system, and, after World War II, make systemic changes to, for example, strengthen private institutions, fund the humanities, organize agendasetting commissions, and create defining structures (Bernstein, 2014; Thelin \& Trollinger, 2014; Wheatley, 2010). Foundation funding for higher education achieved a number of these aims by supporting institutions' existing priorities regarding financial aid, curricular development, research, and capital projects (Bacchetti \& Ehrlich, 2007; Kelly \& James, 2015). Recently, research shows that some large foundations have preferred collective funding across multiple institutions with the goal of accelerating change on policy priorities such as student access, retention, and completion (Bernstein, 2014; Hall, 2011; Kelly \& James, 2015; Rockefeller Philanthropy Advisors [RPA] \& TIAA Institute, 2017). Haddad and Reckhow (2018) reviewed 10 years of grant making by four top foundation funders of higher education, concluding that foundation funding was "converging" on these areas and that there had been a slow decline in traditional support for capital purposes and scholarships. Data from several studies showed a preference among 
foundations for giving to the largest and most prestigious institutions (i.e., research universities) (Bacchetti \& Ehrlich, 2007; Frumkin \& Kaplan, 2010; RPA \& TIAA Institute, 2017).

In contrast, there is little academic research examining corporate philanthropy's implementation within higher education (Clevenger, 2014) and the extant studies usually explore (and find) connections between corporate higher education philanthropy, economic conditions, and social perceptions (Leslie, Drachman, Conrad \& Ramey, 1983; Leslie \& Ramey, 1988). Looking at data over forty years (1967-2007), Van Fleet (2010) found that while gifts in absolute dollars declined during economic downturns, corporate giving as a percent of pre-tax profits stayed relatively stable. Cheslock and Gianneschi (2008) argued that higher levels of state appropriations would generate additional opportunities for corporate benefit and indeed found that corporations contributed more to institutions that received more in state dollars (in a national data set between 1994-2004). One older study of mostly larger companies (1974-1984) found growing corporate funding for research and concluded that this was a strategic, long-term investment aligned with corporate goals (Muller \& Sepehri, 1988).

Building the scholarship on higher education will require more information about how different donor types direct their gifts with consideration of institutional-level differences.

\section{INSTITUTIONAL DIFFERENCES IN HIGHER EDUCATION PHILANTHROPY}

Today, philanthropy provides funds for an average of $10 \%$ of post-secondary sector expenditures (Seltzer, 2018b), making it a relatively small piece of budgets. This statistic, however, masks noteworthy differences among institutions. Considering only public and private, non-profit institutions, which together account for just under $95 \%$ of the total full-time equivalent enrollment across U.S. degree-granting postsecondary institutions (derived from U.S. Department of Education, NCES, 2019, Table 307.10), public institutions average 3.1\% of core revenue funding for annual expenditures from private gifts, grants, and contracts, while private, nonprofit institutions average $19 \% .^{1}$ Fundraising programs have grown exponentially across postsecondary education over the last few decades as more and more institutions invest and find these activities to be revenue positive (Conley \& Tempel, 2006; Gardner, 2017, 2018; Lorin, 2017; Ruffalo Noel Levitz, 2018). Individual institutions may influence donor giving by prioritizing certain needs in their campaigns and presenting particular opportunities to their donors. Moreover, institutional differences in philanthropic outcomes can result from variations in college and university fundraising strategies and investments (Gottfried \& Johnson, 2006; Harris, 1990; Harrison, 1995; Harrison et al., 1995; Proper, Caboni, Hartley, \&Wilmer, 2009).

Private institutions have long been highly motivated to fundraise for donor dollars (Conley \& Tempel, 2006). In the 1980s, as a result of fluctuating state funding, public institutions responded with a new vigor for fundraising. Among similar public and private institutions, the largest beneficiaries of donor dollars 
have typically been the private universities (Conley \& Tempel, 2006; Duronio \& Loessin, 1990; Terry \& Macy, 2007) with elite private research institutions as the most likely candidates for the largest gifts (Bacchetti \& Ehrlich, 2007; Frumkin \& Kaplan, 2010; RPA \& TIAA Institute, 2017). Elite public research institutions, however, are also successful fundraisers, with several regularly appearing among the top 20 fundraisers in the nation (e.g. The Chronicle List, 2018), and some evidence suggests that they are seeing a larger number gifts of $\$ 1$ million and greater than their private counterparts (Indiana University Lilly Family School of Philanthropy, 2013). Some small private colleges and regional public institutions are also receiving mega gifts (Scutari, 2018a, 2018c), though regional publics in particular have faced specific sets of fundraising challenges coming out of the 2008 recession (McClure \& Anderson, 2020). There is evidence that community colleges are building stronger fundraising programs and having some success, but they garner only $1.5-2 \%$ of donations, despite enrolling just under $30 \%$ of all degree-seeking postsecondary students (Indiana University Center for Postsecondary Research, 2019), and available research is limited but growing (Arnim, 2019; Gearhart \& Miller, 2018).

It is worth noting that institutional type may also interact with other variables that can relate to philanthropy such as selectivity (Leslie \& Ramey, 1988; Clotfelter, 2003; Cunningham \& Cochi-Ficano, 2002; Simone, 2009), graduation rates (Gunsalus, 2005), presidential leadership length (Indiana University Lilly Family School of Philanthropy, 2013), and institutional wealth. According to one longitudinal study of private selective colleges and universities (Ehrenberg \& Smith, 2003), wealthier and more prestigious universities raised more money for endowments compared to others where current operations received more support. Well-resourced and prominent institutions are strong fundraisers; alumni and other individuals respond positively to these kinds of drivers (Leslie \& Ramey, 1988; Trow, 1993; Winston, 1999). Leslie and Ramey (1988) and the Indiana University Lilly Family School of Philanthropy (2013) found that larger endowments correlated with more giving, and that high rates of alumni participation in giving are positively associated with million-dollar gifts.

It is evident that philanthropic giving varies by institutional type and control (public vs private) and that fundraising emphases and tactics are evolving. We sought to discover how these phenomena may have been made manifest over the past few decades at four-year institutions in particular.

\section{THREE DECADES OF HIGHER EDUCATION GIVING: A LONGITUDINAL ANALYSIS}

Given the need for additional research about variations in behaviors among donors and differences in philanthropy among institutions as well as the importance of information about philanthropic support for institutional initiatives, our research questions were: How have the purposes that donors support changed over time? How and for what purposes do different groups of donors give across institutions? 
We employed data from the CASE VSE survey supplemented with data from the NCES Integrated Postsecondary Education Data System (IPEDS). The VSE survey began in 1957, provides a national sample, and is regarded as the definitive source documenting U. S. higher education, most recently encompassing 79.7\% of total voluntary support for higher education and representing about a third of colleges and universities (CASE, 2019a). ${ }^{2}$ The NCES surveys began in the 1980s and provide comprehensive institutional portraits related to student enrollments, academic programs, finances, human resources, and an array of other institutional characteristics. A working paper reporting on the study was first published by the TIAA Institute (Shaker \& Borden, 2020).

\section{Methodology}

We identified a longitudinal sample of 395 public and private postsecondary institutions, including several large systems that comprise multiple institutions, thus representing around 430 individually accredited postsecondary institutions. These institutions completed the VSE survey in the years 1988, 1998, 2008 and 2018. Using VSE responses, we present a descriptive analyses of giving at the sampled institutions across 30 years. We explore patterns in giving for different types of donors and gift purposes. We use standard characteristics to examine differentiation by institutional type among our sample of mostly four-year institutions. These characteristics include the basic Carnegie Classification broad categories and institutional control. By focusing on a panel that completed the full VSE survey at the chosen time points, we removed as a confound changes due to new institutions and the few that closed or merged since 1988.

Donor Type

For the current analysis, we divide the donors into individual donors (alumni and other individuals) and organizational donors (foundations, corporations, and other organizations) (See Appendix A-Table 1A).

Donation Purposes

The VSE survey first distinguishes between two broad purposes: current operations and capital/endowment. Current operations are divided into unrestricted and restricted. Restricted purposes are then further detailed into nine categories. Capital/endowment is divided into four sub-purposes. The detailed structure is as follows, with specifications provided in Appendix A-Table 2A.

\section{- Current Operations}

- Unrestricted

- Restricted

- Academic divisions

- Faculty/Staff

- Research

- Public Service 
- Libraries

- Physical Plant

- Student Aid

- Student Athletics

- Other Purposes

\section{- Capital/Endowment}

- Property, buildings, equipment

- Unrestricted endowment

- Restricted endowment (outright plus deferred)

- Loan Funds

For the analysis, we include institutions that had non-missing values for the sub-purpose levels of current operations and capital/endowment purposes. Our data also reflect some changes in the survey over time. For example, among detailed purposes of restricted current operations, the VSE did not separate out donation amounts to support student athletics before 1998 and, in that first year of collecting this information, reporting was inconsistent, with some institutions providing that subtotal and others not.

We extracted from IPEDS data institutional characteristics related to control (public/private) and 2015 Carnegie Classification. In the VSE data, some institutions with multiple accredited campuses were reported as a single organization (e.g. Indiana University) while some others have data for individual campuses (e.g. University of California system). In our analysis, we matched the IPEDS data to individual campuses and created an aggregated multi-campus organization as a category for those organizations that report their philanthropic activity at the system level and are comprised of multiple campuses in different Carnegie categories. The individual campus data were also aggregated for these multi-campus organizations when determining, for example, overall enrollments.

\section{FINDINGS}

We situate our sample by comparing it to all 2018 VSE respondents (VSE2018) as well as all U.S. accredited, degree granting institutions (All DG), and all U.S. four-year, comprehensive degree granting institutions (4YrCmp). The study sample $(\mathrm{n}=395)$ over-represents public institutions (Figure 1). It is also skewed heavily toward 4-year, comprehensive (not specialized) institutions, and includes only a handful of associate's and specialized four-year institutions (Figure 2).

The longitudinal sample also over-represents doctoral/research universities, especially compared to the broadest, "all degree-granting" institution population (Figure 2). The sample and the 2018 VSE responding population are relatively similar in the proportions of master's and baccalaureate institutions, both overrepresenting these groups in comparison to the all-degree granting population. However, both the sample and the 2018 VSE responding pool under-represent master's universities among the four-year comprehensive comparison group. 


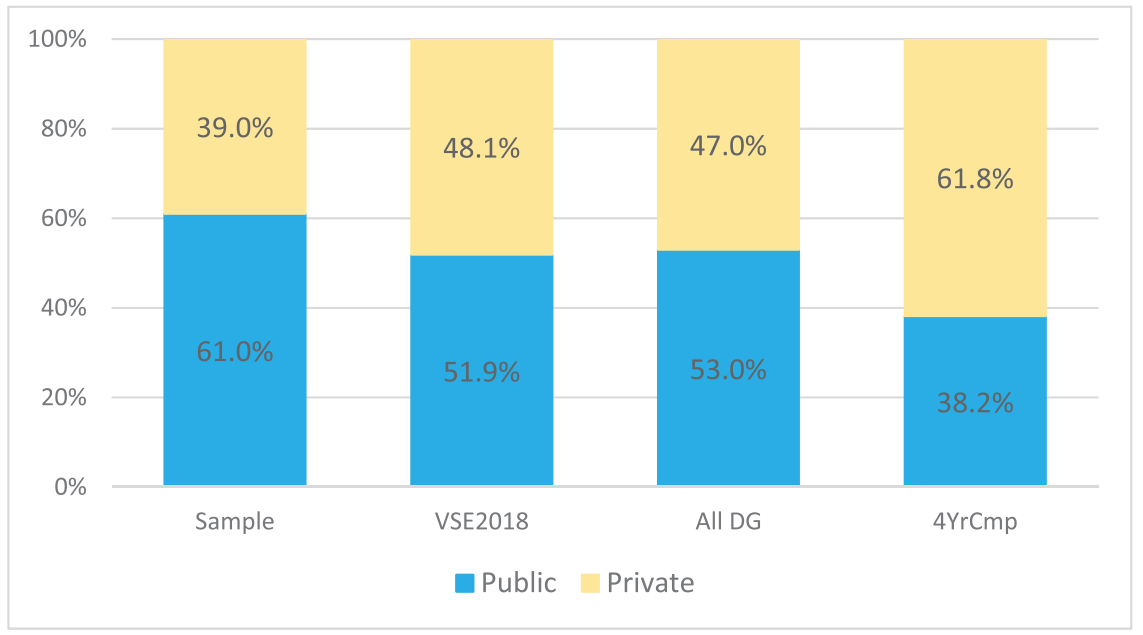

Figure 1. Control of sample and comparison group institutions.

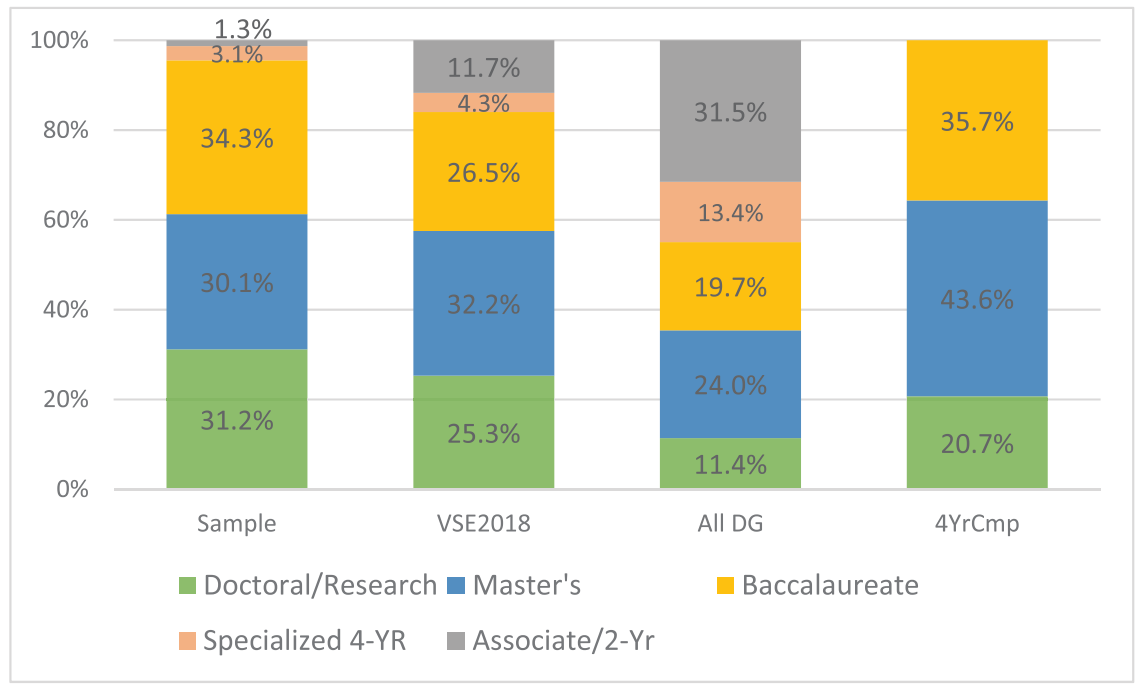

Figure 2. Carnegie category of sample and comparison institutions.

Table 1 provides a comparison between the longitudinal sample and the VSE respondent population of reported donation activity for 2018, by purpose and donor type. Although representing only $42 \%$ of responding institutions, this longitudinal sample accounts for two thirds of all reported donations. Generally, the sample is similarly distributed by purpose and by donor type compared to all 2018 VSE respondents.

The remainder of the analysis focuses on longitudinal findings and interpretation. The representation issues noted in this section should be kept in mind throughout this analysis. 
Table 1. Donation Activity (in \$ thousands) Reported in 2018 VSE by the Longitudinal Sample Compared to all Survey Respondents

\begin{tabular}{lcc|cc|c}
\hline & \multicolumn{2}{c|}{ Sample (N=395) } & \multicolumn{2}{c|}{ VSE 2018 (N=931) } & Sample as \% \\
\cline { 2 - 5 } & Amount & $\mathbf{9}$ & Amount & $\mathbf{9}$ & 2018 \\
\hline Total Giving & $\mathbf{2 5 , 1 0 3}$ & & $\mathbf{3 7 , 7 1 0}$ & & $\mathbf{6 6 . 6 \%}$ \\
Current Operations & $\mathbf{1 4 , 3 6 9}$ & $\mathbf{5 7 . 2 \%}$ & $\mathbf{2 1 , 5 9 5}$ & $\mathbf{5 7 . 3 \%}$ & $\mathbf{6 6 . 5 \%}$ \\
$\quad$ Restricted & 1,494 & $6.0 \%$ & 2,385 & $6.3 \%$ & $62.6 \%$ \\
$\quad$ Unrestricted & 12,875 & $51.3 \%$ & 19,210 & $50.9 \%$ & $67.0 \%$ \\
Capital/Endowment & $\mathbf{1 0 , 7 3 4}$ & $\mathbf{4 2 . 8 \%}$ & $\mathbf{1 6 , 1 1 5}$ & $\mathbf{4 2 . 7 \%}$ & $\mathbf{6 6 . 6 \%}$ \\
$\quad$ Property, buildings, & 3,078 & $12.3 \%$ & 4,575 & $12.1 \%$ & $67.3 \%$ \\
$\quad$ equipment & & & & & \\
$\quad$ Unrestricted endowment & 324 & $1.3 \%$ & 767 & $2.0 \%$ & $42.2 \%$ \\
$\quad$ Restricted endowment & 7,328 & $29.2 \%$ & 10,766 & $28.5 \%$ & $68.1 \%$ \\
$\quad$ Loan funds & 4.0 & $0.0 \%$ & 6.7 & $0.0 \%$ & $58.6 \%$ \\
\hline Alumni & 6,538 & $26.0 \%$ & 10,493 & $27.8 \%$ & $62.3 \%$ \\
Other Individuals & 4,673 & $18.6 \%$ & 7,234 & $19.2 \%$ & $64.6 \%$ \\
Foundations & 7,526 & $30.0 \%$ & 10,600 & $28.1 \%$ & $71.0 \%$ \\
Corporations & 3,594 & $14.3 \%$ & 5,382 & $14.3 \%$ & $66.8 \%$ \\
Other Organizations & 2,772 & $11.0 \%$ & 4,001 & $10.6 \%$ & $69.3 \%$ \\
\hline
\end{tabular}

\section{Overall Giving}

In the thirty-year study period (1988 through 2018), unadjusted dollar giving to the institutions in the sample increased by an average annual rate of $6.3 \%$ for an overall increase of $488 \%$ in unadjusted dollars from $\$ 4.272$ billion to $\$ 25.103$ billion (See Table 2). When adjusted for inflation to 2018 dollars, the increase was still dramatic at an annual average of $3.6 \%, 175 \%$ overall, from $\$ 9.124$ billion to $\$ 25.103$ billion (See Figures 3 and 4 ). The most rapid period of growth occurred between 1988 and 1998 (69\% overall, 5.4\% average annual rate of change) before slowing down subsequently. Philanthropic giving in the United States also increased as a whole between 1988 and 2018; the inflation adjusted annualized rate of change during that period was $2.8 \%$ (Giving USA Foundation, 2019). Previous research has found variations in giving to higher education to be tied to some major economic indicators, such as growth in personal income, unemployment indicators, and to fluctuations in the stock market but shifts in giving to higher education following recessions in particular are not as distinct or lasting as in giving to other causes (Drezner, 2006; Frank, 2014).

Several periods within this study were marked by growth in many postsecondary institutions' investments in administration (McClure \& Titus, 2018), though there were also some cuts due to the 2008 recession and declines in 


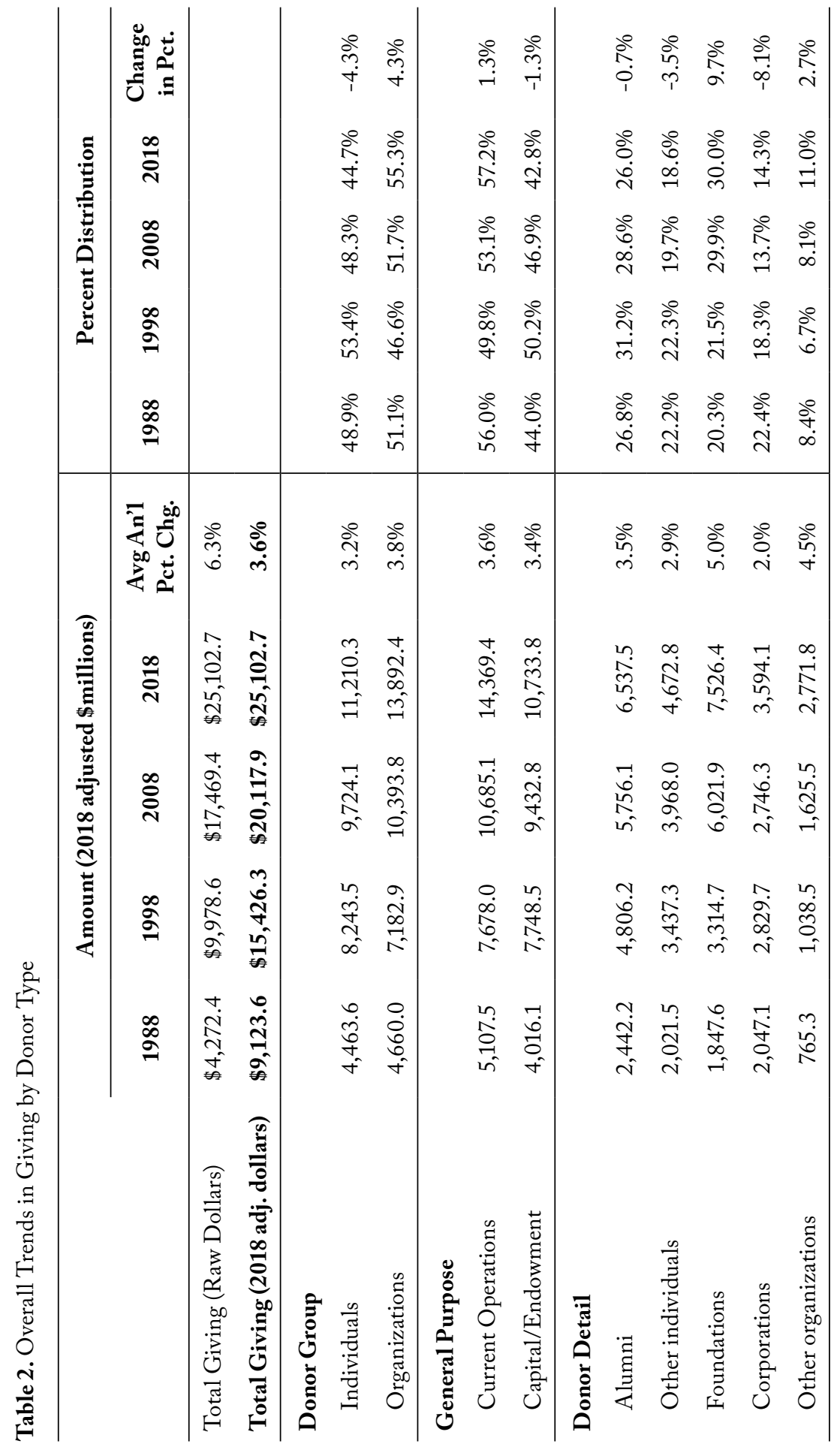


state appropriations (McClure \& Anderson, 2020). Still, many saw investments in advancement programs as institutions began moving into "constant campaign mode," which entailed a more consistent approach to fundraising staffing and philanthropy's enhanced role as a core, revenue-generating activity (Conley \& Tempel, 2006; Drezner, 2011; Lorin, 2017; Thelin \& Trollinger, 2014). Fundraising staff size has been found to be positively related to dollars raised (Kroll, 2012; Proper et al., 2009). It seems likely that there is a relationship between institutional commitments to advancement and the increases in philanthropy documented here.

\section{Donor Type}

In 1988, individuals and organizations contributed to the institutions at similar financial levels: $\$ 4.464$ billion and $\$ 4.660$ billion, respectively in 2018 adjusted dollars, a difference of $2.2 \%$. But by 2018 , the difference was greater $(10.6 \%)$ and reversed with individuals giving less ( $\$ 11.210$ billion) than organizations $(\$ 13.892$ billion) (See Table 2).

In the organizational category, giving among foundations grew by nearly $5 \%$ annually, thereby increasing the share accounted for by foundations by almost 10 percentage points while the proportion of giving by those in the category of "other organizations" increased by nearly 3 points. The proportion of giving by corporations shrank about 8 percentage points. The large rise in foundation giving can perhaps be explained by the increasing number of private family foundations, growing foundation assets, and more grant making in the last 20+ years (Foundation Center, 2019). Some advancement teams strengthened their foundation-related expertise and support for faculty and staff who also seek foundation funding. These efforts may have improved foundation fundraising inputs and outputs. Considering U.S. philanthropic giving generally, corporate donations as a percentage of pre-tax profits declined during the study period, but profits have increased exponentially (Giving USA Foundation, 2019). This means that corporations still give more to nonprofits in the current time than ever before. In this study, corporations did give more money but had the lowest rate of growth. Perhaps their increasingly strategic and bottom-line driven philanthropic model (Clevenger, 2014) has led corporations to distribute more of their philanthropic dollars to other cause priorities instead of colleges and universities.

Of all the donor types, alumni support has been the most consistent across the decades beginning at $26.8 \%$ of donated dollars and ending at $26.0 \%$, with a bump to $31.2 \%$ in between. This is particularly interesting considering reported declines in the proportion of alumni who make donations (Blackbaud, 2018; CASE, 2019b; Scutari, 2018c) and that the majority of the dollars come from fewer and fewer of donors (Thelin \& Trollinger, 2014). The relative proportional consistency of alumni giving generally may relate to the "standard" advancement model of organizing a significant amount of fundraising effort around alumni affiliations. Moreover, a great deal of research has been conducted to help practitioners understand alumni giving proclivities (Proper \& Caboni, 2014). 
Alumni giving increased by $3.5 \%$ on average annually while other individuals' giving went up by $2.9 \%$. The alumni-based fundraising model may also relate to a slower rate of increase in other individuals' giving and a general decline in the proportion of support from other individuals. Structures for fundraising are not as thoroughly developed around the needs of these non-alumni donors (i.e., faculty, staff, parents, community members) (Drezner, 2013).

\section{Gift Purpose}

More was given for current operational needs rather than capital/endowment purposes, except in 1998 when there was near parity (49.8\% for current operations) (See Table 3). From the beginning of the study period to the conclusion, current operations and capital/endowment increased from $\$ 5.108$ billion to $\$ 14.369$ billion and $\$ 4.016$ billion to $\$ 10.734$ billion, respectively, for a 1.3 change in percent towards current operations giving. Giving for the two broad purposes has increased at a similar rate of average annual change (3.4\% for capital/endowment and 3.6\% for current operations) with the sharpest increase for capital/endowment coming in the first ten-year span of the study and for current operations in the last ten-year period. The emphasis on near-term and temporary purposes became most evident after 2008, perhaps reflecting concerns about making long-term gifts stemming from the great recession's toll on university endowments and growing doubts about endowment management, use, and appropriateness (The Chronicle of Higher Education, 2018; Kim, 2017; Oxtoby, 2015; Thelin \& Trollinger, 2014). Gifts to capital/endowment purposes have also generally "softened" following stock market declines, according to CASE (2019a) analysis of the VSE.

The prioritization of restricted over unrestricted support was evident in both major purpose categories (See Table 3 and Figure 3). This study period coincides with a stronger emphasis on major gift fundraising (building upon the traditional, annual giving approach) by colleges and universities (Thelin \& Trollinger, 2014). Requests for large contributions tend to focus on matching specific donor interests with specific organizational needs (Nyman, Pilbeam, Baines \& Maklan, 2018), larger gifts tend to be restricted at least to some degree, and higher education receives more large gifts ( $\$ 1$ million and more) than any other nonprofit subsector (Indiana University Lilly Family School of Philanthropy, 2013). This is in comparison to annual gift fundraising, which more frequently is for general support and for which the gifts tend to be smaller (Thelin \& Trollinger, 2014).

Capital/endowment donations were disaggregated into four groupings: property, buildings, and equipment; unrestricted endowment; loans; and restricted endowment. Restricted, endowed purposes have received an absolute majority of gifts, ranging from $50.8 \%$ (1988) to $68.3 \%$ (2018) of the gifts for an increase in proportion of 17.5 percentage points. Donor support for buildings and equipment, which represented over 36\% of capital/endowment purpose funding in 1988, dropped to about 30\% in 1998 and remained at that level through 2018. Unrestricted endowments never constituted more than $12.1 \%$ of the funding category and showed an inconsistent pattern, beginning with a high of $\$ 487$ million 


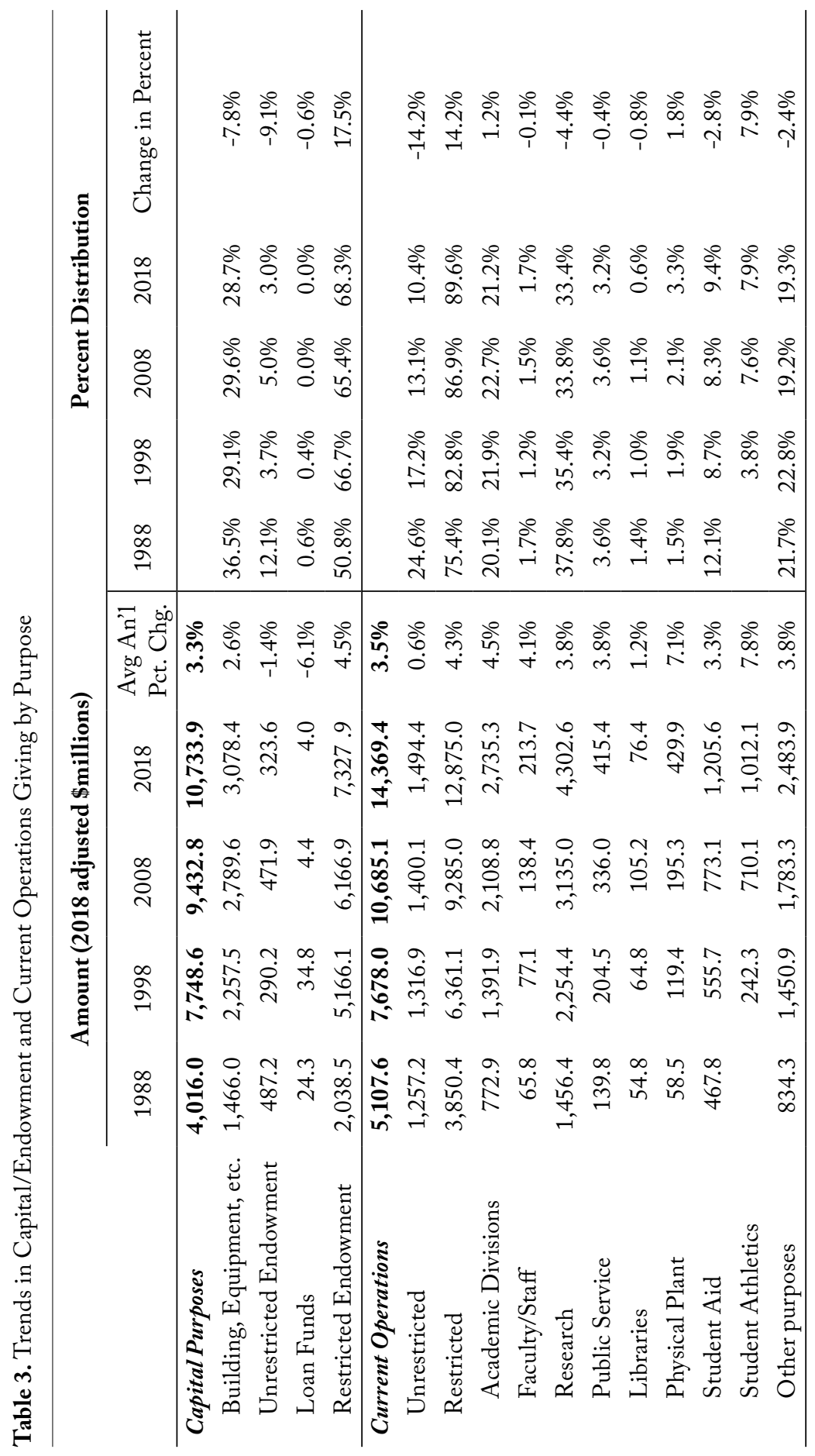




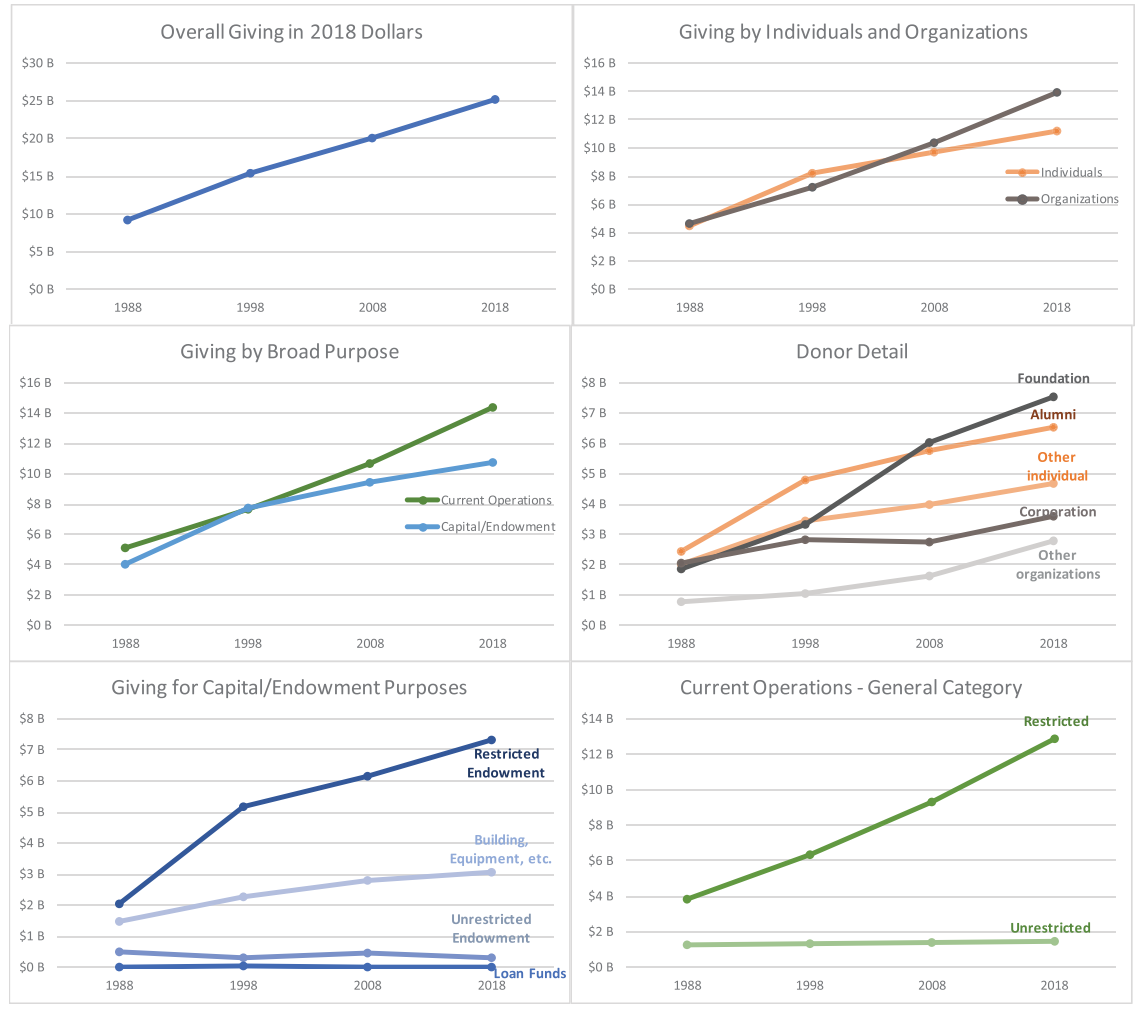

Figure 3. Trends in giving by purpose (general and major) and donor type.

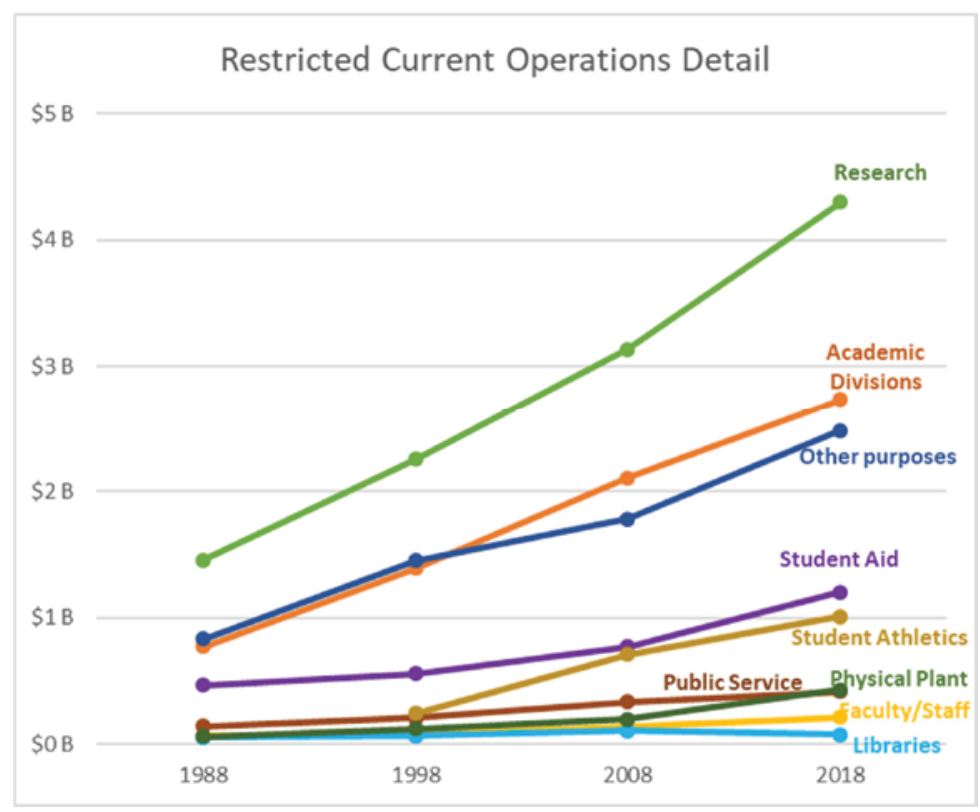

Figure 4. Trends in purposes for restricted current operations giving. 
in 1988, declining, recovering to some degree, but then declining to the lowest point of $\$ 324$ million in 2018 .

In the current operations purposes funding, the trend toward restricting gift purposes was even stronger (see Table 3, Figures 3 and 4). Unrestricted current operations dollars accounted for $24.6 \%$ of the funds in this category in 1988 but only $10.4 \%$ in 2018 - this was an increase of just around $\$ 250$ million during the study. Donors' purposes in their current operations support were diverse, with no single purpose receiving more than $40 \%$ of the dollars at any given time. Research, which can include anything from basic and theoretical research by individual faculty to more applied studies completed by academic centers, received the largest share of current operations funding across the decades-around one-thirdthough it did decrease in proportion over time. The attention to research purposes seems to reflect ongoing, positive public sentiment related to research outcomes as evidenced in a recent study that found more than $80 \%$ of respondents agreed that higher education contributes scientific advances to American society (Drezner et al., 2018). The second most prominent priority, academic divisions, maintained a fairly stable proportion of total funding of between $20-23 \%$ of the funding. This funding is limited by use by a particular academic unit but allows for flexibility otherwise. Physical plant and athletics saw the greatest increases in support, but physical plant was one of the smaller categories and athletics was not differentiated in the data prior to 1998, making comparison to the other categories more difficult.

Current operations support for student aid garnered one of the lowest average annual increase rates (3.3\%) and a shrinking proportion of the gifts (from a 12.1\% high in 1988 to $9.4 \%$ in 2018). Only after 2008 did gifts for this purpose reach the $\$ 1$ billion mark. This was a surprising finding in consideration of rising college costs and related public outcry and concern (Ma, Baum, Pender, \& Libassi, 2018; Mitchell, Leachman, \& Masterson, 2016; Webber, 2017). Other VSE data, however, show that more than a third of donors' restricted endowment giving supports students financial aid and indicate that this emphasis is historically consistent (CASE, 2020). Donors may also be supporting student access, retention, and completion through programmatic grants and gifts to institutions rather than in direct student support (Bernstein, 2014; Hall, 2011; Kelly \& James, 2015; RPA \& TIAA Institute, 2017); these contributions may be in the other restricted purposes category.

\section{Gift Purpose by Donor Type}

\section{Current Operations Unrestricted Giving}

Individuals have been more likely than organizations to make unrestricted gifts (See Figure 5). Foundations, corporations, and other organizations left only $5.6 \%, 5.3 \%$, and $5.9 \%$ respectively, of their current operations support to institutional discretion by 2018-declines in proportion of their support for this purpose from 1988. Other organizations gave approximately the same amount in 1988 for this purpose and corporations gave less than before. The de-emphasis on unrestricted giving is not surprising given that organizational donors tend to have purpose-specific guidelines and expectations associated with their giving, 


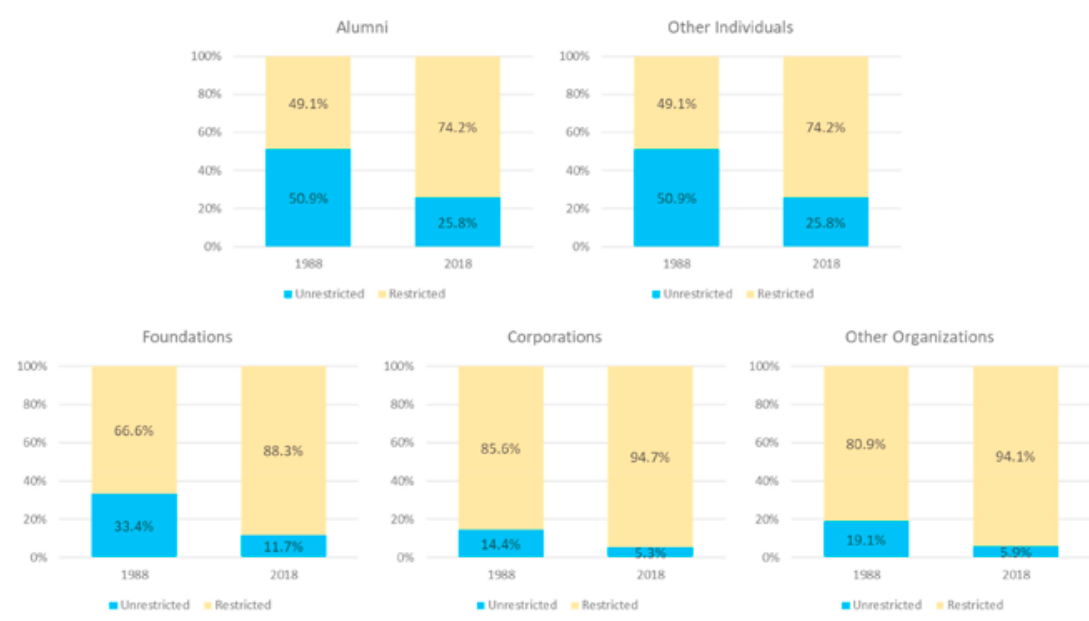

Figure 5. Restricted and unrestricted current operations giving by donor type.

and formalization of these practices has tended to increase over time (Bernstein, 2014; Clevenger, 2014). Of all the donor types, alumni give the largest proportion and dollars in unrestricted gifts, which seems to fit with the depth and diversity of their organizational attachments (Drezner, 2011). They dedicated 50.9\% (\$558 million) of their current operations support to this purpose in 1988. However, by 2018 , they left only $25.8 \%$ unrestricted ( $\$ 715$ million). This change in alumni behavior is striking and perhaps may relate to the trend away from small gifts toward larger, focused contributions and the associated fundraising strategies (Thelin \& Trollinger, 2014). Other individuals' unrestricted giving also declined in proportion from a high of $33.4 \%$ (1988) to just $11.7 \%$ (2018) and they actually gave less money for this purpose over time.

\section{Capital/endowment}

All donor types prioritized restricted over unrestricted giving for capital/ endowments and this tendency increased for all but one type over the study time period. Restricted endowment gifts as a category accounted for $\$ 2.038$ billion in 1988 and $\$ 7.328$ billion in 2018 (See Table 3). The proportion of capital/endowment contributions for this purpose increased for every donor type between 15-30\%, ending in 2018 as follows: alumni (69.3\%), other individuals (75.9\%), foundations (64.9\%), corporations (55.2\%), and other organizations (67.1\%) (See Figures 6 and $7)$. Other forms of restricted endowment support include gifts for property, buildings, and equipment and for loan funds. In 1988, organizational donors prioritized property, buildings, and equipment to a greater degree, but this support appeared to shift toward other forms of restricted endowment support by 2018. Changes in individual giving to property, buildings, and equipment overtime, however, have been less dramatic, with the proportion of support hovering around $20-25 \%$ and a lower annual rate of change. Loan funds were always a tiny proportion of the giving and declined in amount and proportion for four of the five donor types over time. 


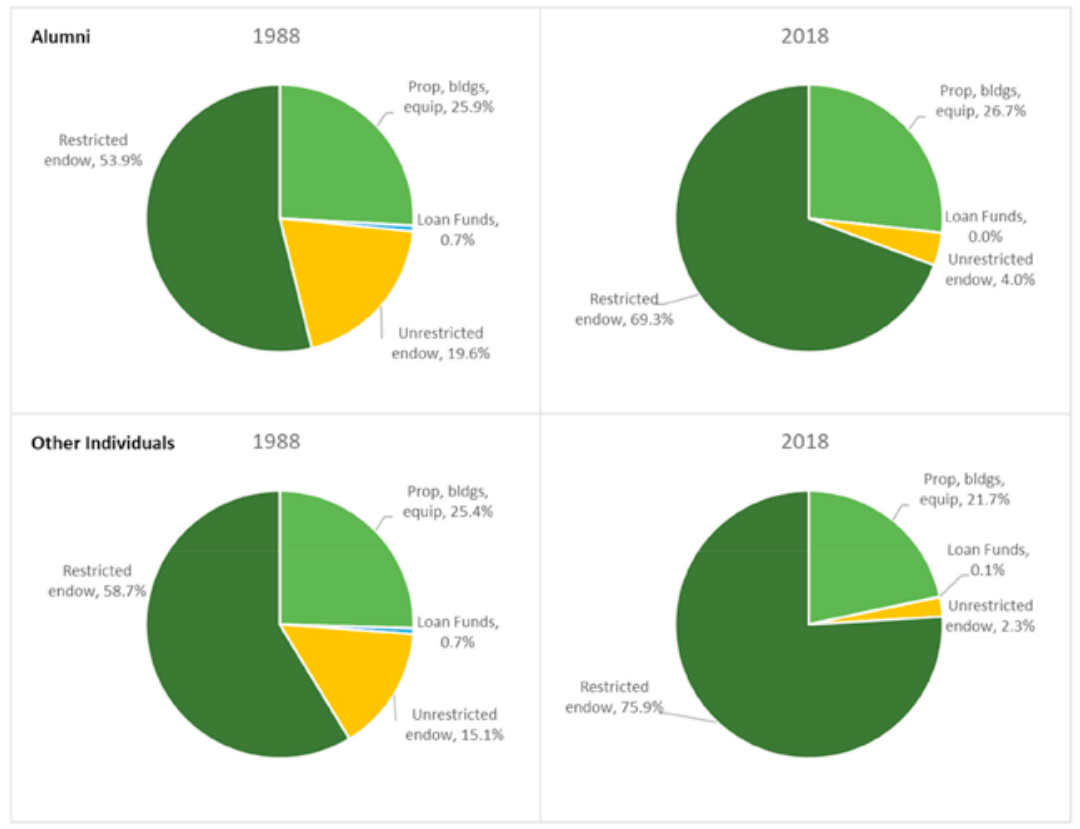

Figure 6. Changes in proportional giving for capital/endowment purposes by individual donors.

When the study first began, individuals gave a higher proportion for unrestricted endowed purposes (4.7\%) than did organizations (3.4\%) but by the end the proportions were closer $(3.3 \%$ and $2.6 \%)$. The most notable declines in giving for this purpose came among individual donors: alumni gave $19.6 \%$ of their endowed contributions without restriction in 1988, but only $4.0 \%$ for this use in 2018 and other individuals gave $15.1 \%$ and $2.3 \%$ in those years (See Figure 6). The move away from unrestricted support may again reflect a number of advancement trends including the highly personalized nature of individual major gift fundraising, thematic campaign fundraising, and donor inclination to be more engaged and involved in the handling of their philanthropy (Drezner, 2013; Thelin \& Trollinger, 2014). Other organizations (i.e., churches, associations) were the only population whose unrestricted endowment giving grew proportionately over the study period from $5.6 \%$ to $6.7 \%$, but it is a relatively small change with modest financial consequences (See Figure 7). Total unrestricted endowment giving only equaled $\$ 324$ million in 2018, making it a lesser share of the approximately $\$ 25$ billion donated that year (See Table 3).

\section{Current Operations Restricted Giving}

Tables 4 and 5 and Figures 8 and 9 provide a representation of individuals' and organizations' current operations restricted giving priorities. Key results by donor type and the proportion of their giving dedicated to each purpose are summarized here, keeping in mind that this information should also be considered in light of the varying amounts contributed by each group. The behaviors of the 


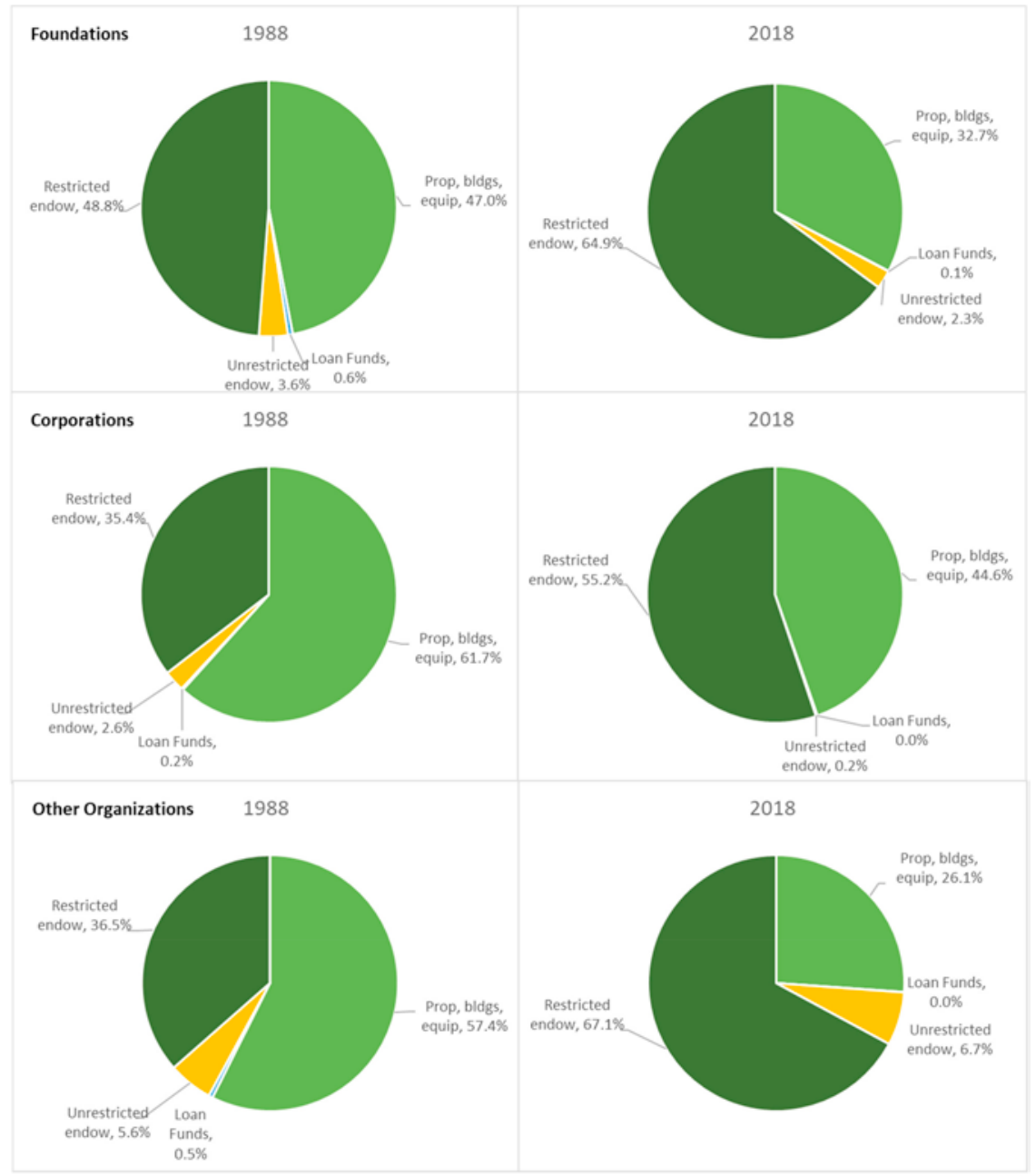

Figure 7. Changes in proportional giving for capital/endowment purposes by organizational donors.

particular groups of donors toward specific forms of support may be associated with some of the rationales described in the prior sections (i.e., different forms of donor motivation and purposes among individual and organizational donors, adaptions in fundraising strategies, investments, and priorities over time).

- Alumni support for academic divisions declined (36.8\% to $26.1 \%)$ as did giving for all other purposes (40.7\% to $28.0 \%)$. Giving for student aid also declined to a lesser degree (15.8\% to $14.9 \%)$ and research support was flat (6.7\% to $6.6 \%)$. Athletics support, measured independently after 1998, constituted $24.3 \%$ of the donated dollars by 2018 .

- Other individuals' giving to academic divisions increased in proportion (19.8\% to 22.0\%). Athletics garnered $13.7 \%$ of the funding by 2018. Support for all other purposes went 


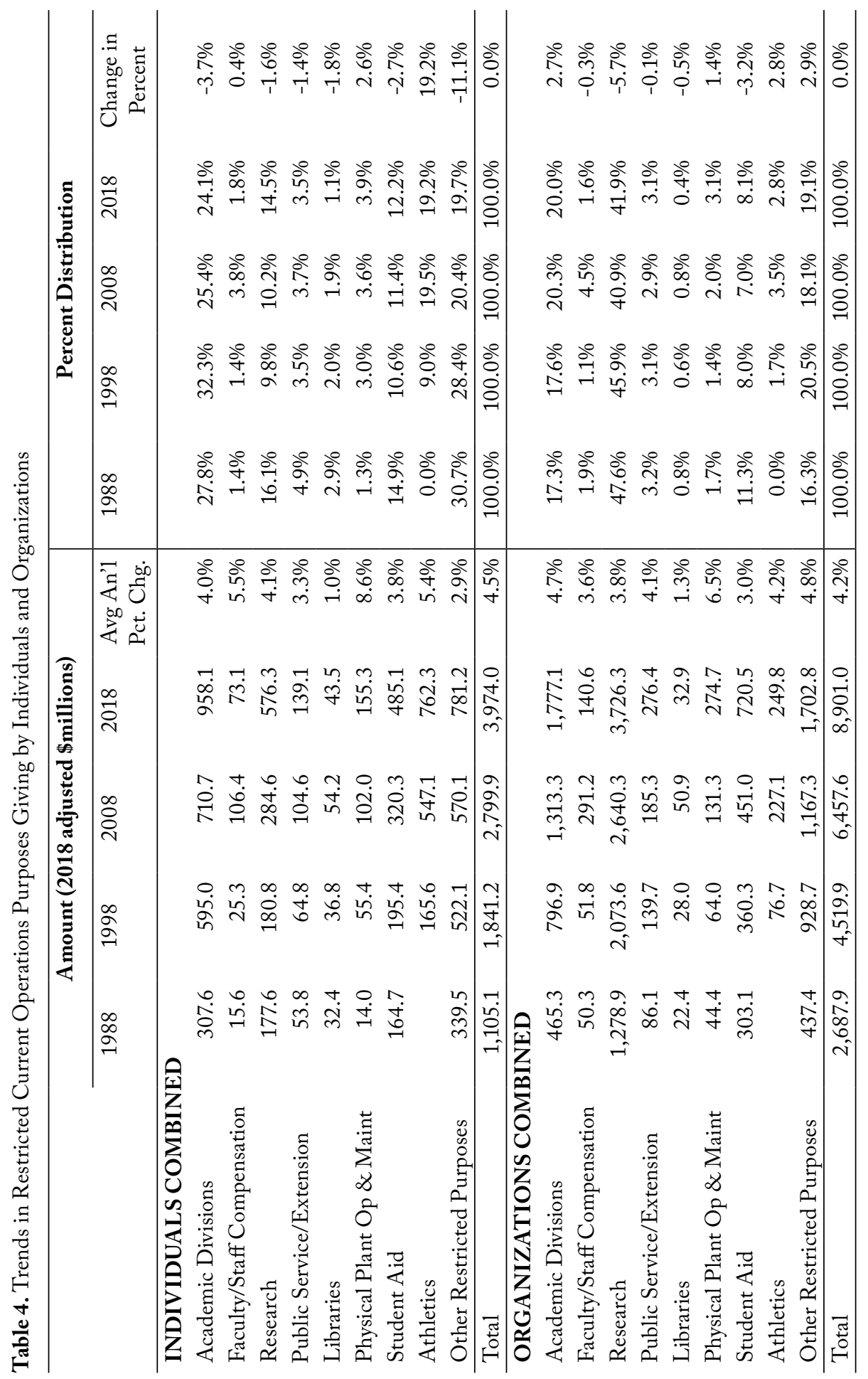




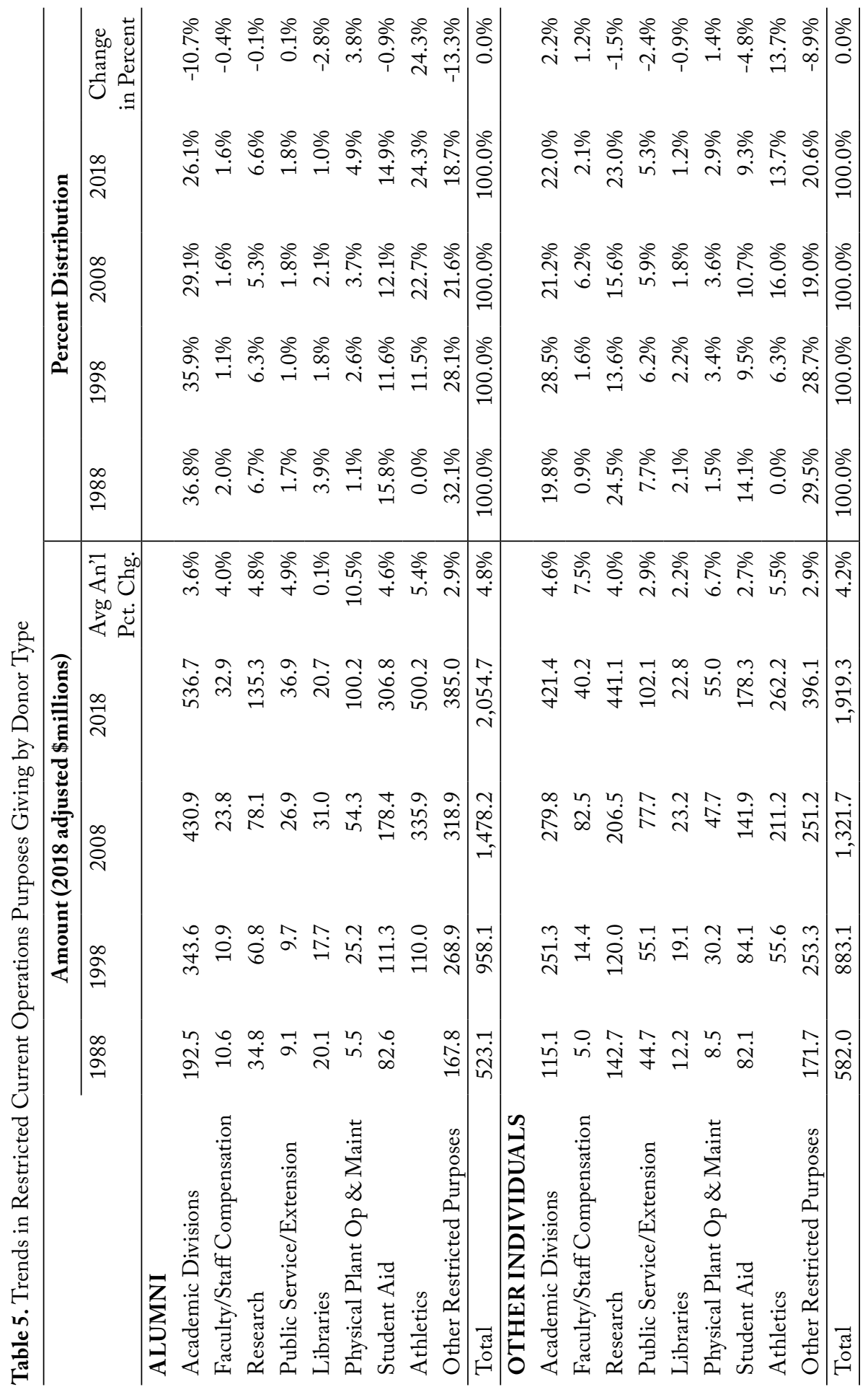




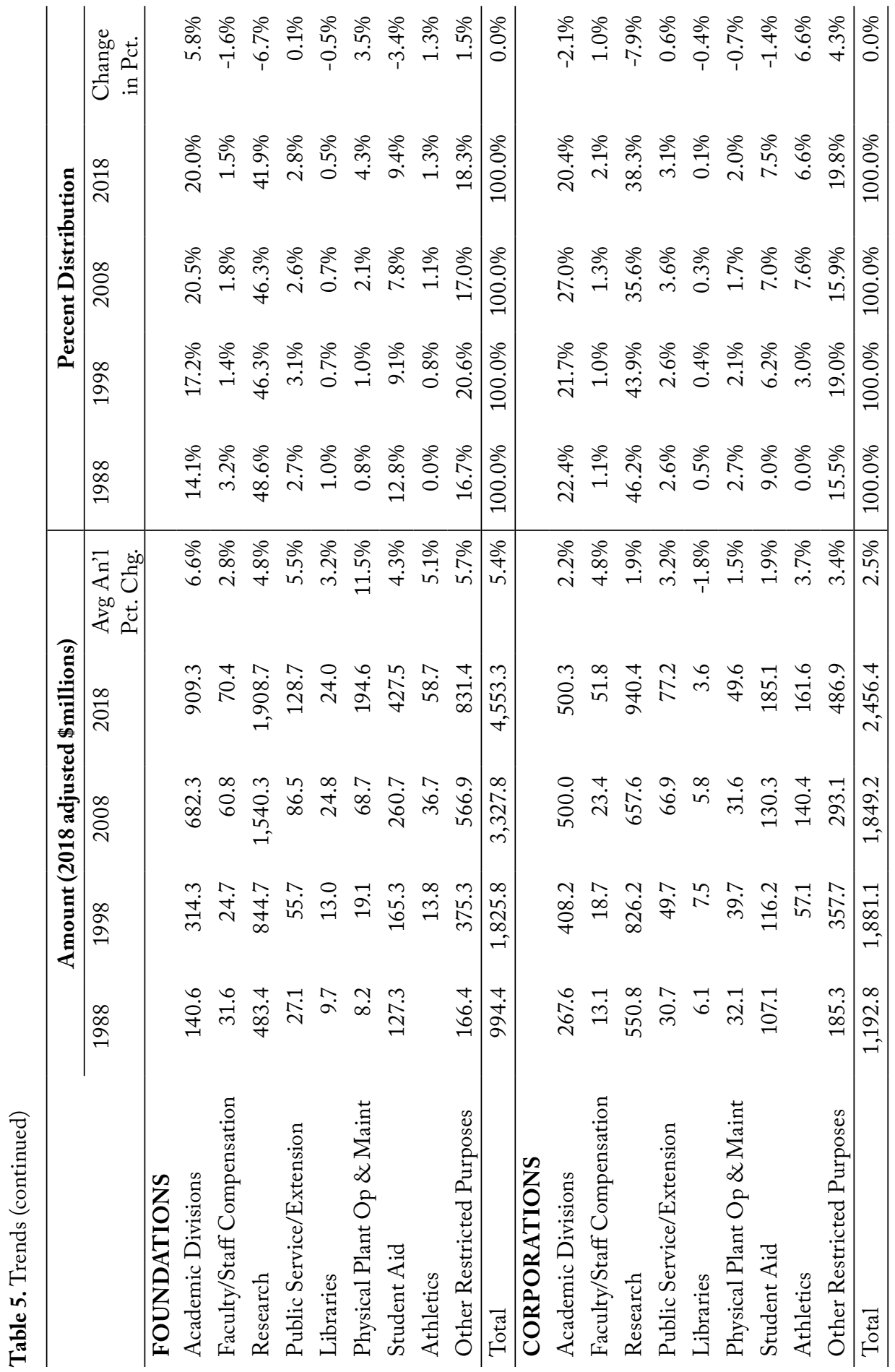




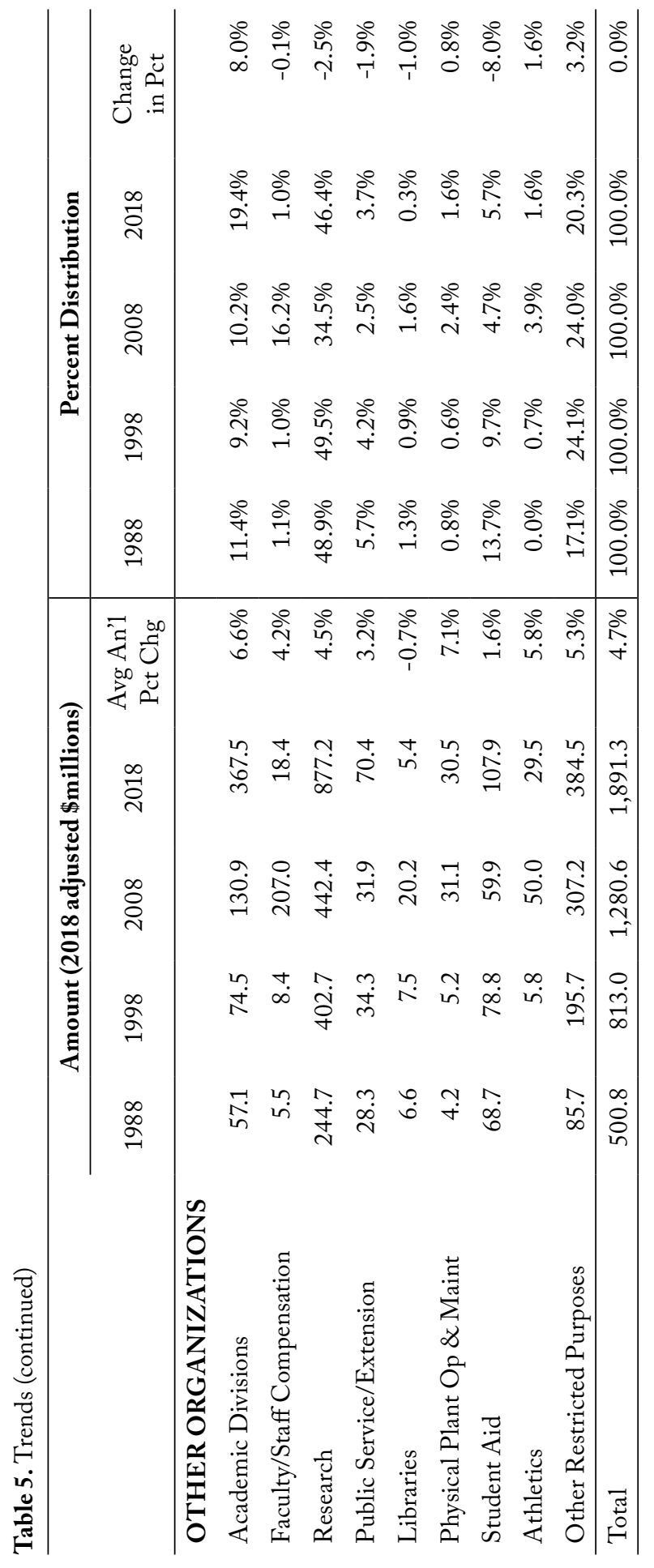


down (41.6\% to $32.1 \%)$ as did student aid support (14.1\% to $9.3 \%)$. Research dollars also declined, albeit by fewer percentage points ( $24.5 \%$ to $23.0 \%)$

- Foundations' support for all other purposes and academic divisions rose (24.4\% to $27.4 \%$ and $14.1 \%$ and $20.0 \%$, respectively). Giving for research went down (48.6\% to $41.9 \%)$ as did student aid funding (12.8\% to 9.4\%). Support for athletics was minimal (1.3\%).

- Corporations' giving increased for all other purposes (22.4\% and $27.2 \%)$ and declined for academic divisions (22.4\% to $20.4 \%$ ). Research support also went down (46.2\% to $38.3 \%$ ) as did student aid dollars (9.0\% to 7.5\%). Athletics received $6.6 \%$ of corporate dollars in 2018 .

- Other organizations increased their support for academic divisions (11.4\% to $19.4 \%)$ and slightly raised the proportion given for all other purposes (26.0\% to $26.9 \%)$. They gave less for research (48.9\% to $46.4 \%)$, but the greatest decline came in for student aid (13.7\% to $5.7 \%)$

\section{Giving by Institutional Control}

Private institutions received more funding in 1988 than public institutions ( $\$ 5.270$ billion compared to $\$ 3.854$ billion), but by 2018 , the public institutions received more than the privates, by about $\$ 700$ million ( $\$ 12.763$ billion compared to $\$ 12.057$ billion) (See Table 6). This study coincided with declines in once stable state appropriations, which could be hypothesized to lead to institutional desire and donor interest in making up the difference in lost funding philanthropically.

\section{Alumni}
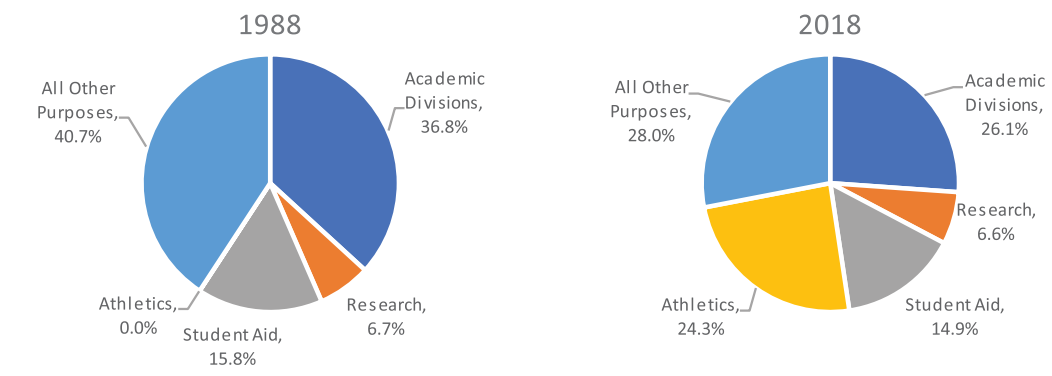

Other Individuals
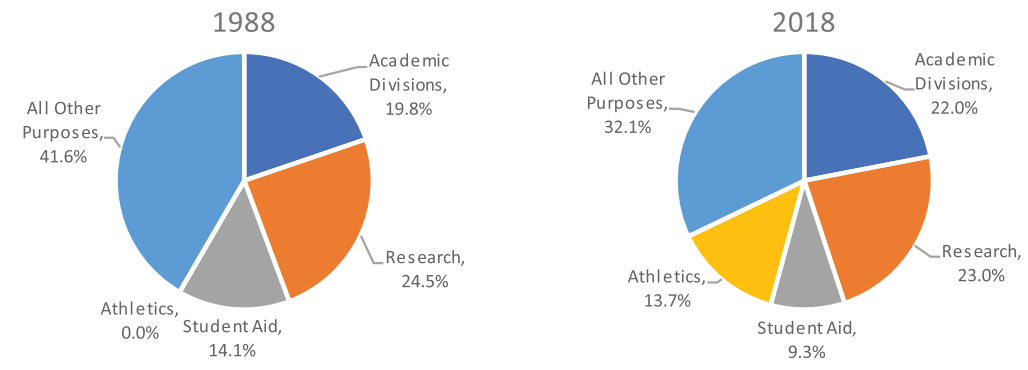

Note: All Other Purposes includes: Faculty/Staff Compensation, Public Service/Extension, Physical Plant, Libraries, and Other Restricted Purposes

Figure 8. Changes in purposes for restricted current operations giving by individual donor type. 


\section{Foundations}
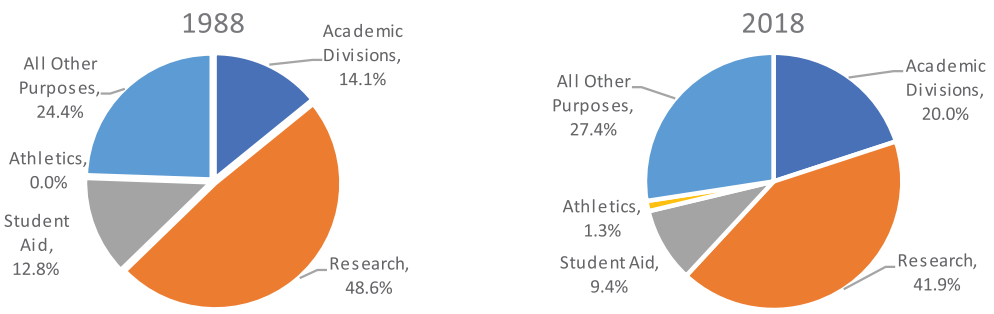

\section{Corporations}
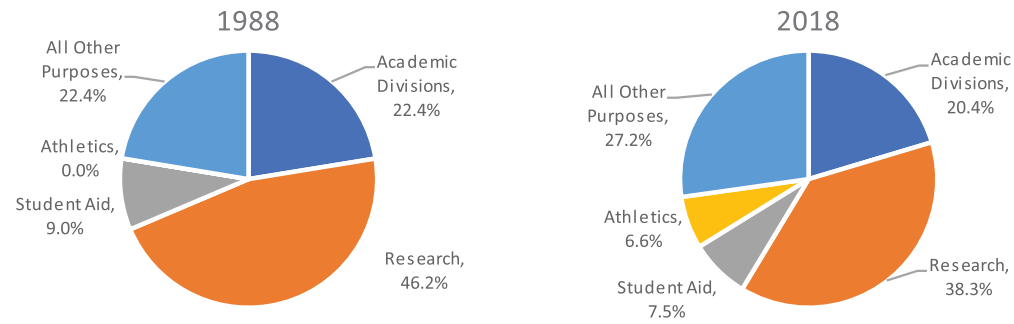

\section{Other Organizations}
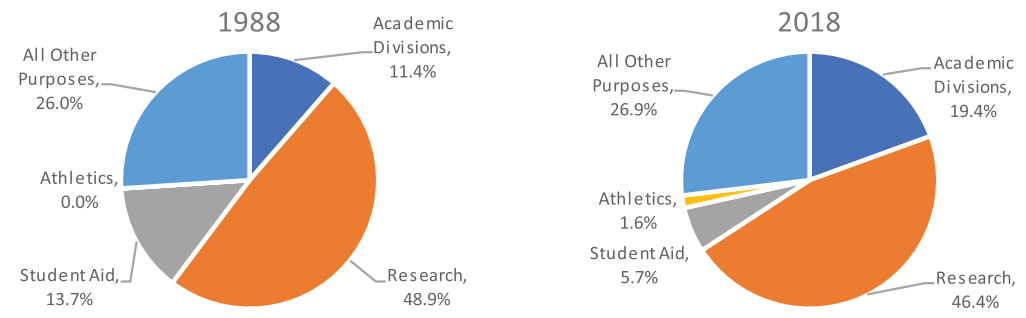

Note: All Other Purposes includes: Faculty/Staff Compensation, Public Service/Extension, Physical Plant, Libraries, and Other Restricted Purposes

Figure 9. Changes in purposes for restricted current operations giving by organizational donor type.

Leslie and Ramey (1988), however, found that increases in state funding appeared to decrease individual donations for all donor types except businesses. Cheslock and Gianneschi (2008) discovered a slight positive relationship between state appropriations and private donations, suggesting that although there may have been an aggregate effect of raising more funds among public institutions, the relationship was not evident at the institutional level. Newer research in higher education and for nonprofit organizations documents little connection between levels of philanthropic donation and government support (Fukui, 2020; Lu, 2016). Fundraisers also report that alumni and others evidence little knowledge about changes in state appropriations (McClure \& Anderson, 2020) making it unlikely 
that this affects their giving behaviors. Other explanations are needed to understand the rise in philanthropic support for public institutions. One consideration is that during this time many public institutions recognized philanthropy as an underdeveloped revenue stream and invested in their fundraising programs (Conley \& Tempel, 2006); this certainly may have affected donations.

Table 6. Current Operations and Capital Donations by Institutional Control, Carnegie Category: Changes between 1988 and 2018

\begin{tabular}{lrrr|rrr}
\hline & \multicolumn{3}{c|}{$\mathbf{1 9 8 8}$ (2018 adjusted } & \multicolumn{3}{c}{ 2018 (\$millions) } \\
& \multicolumn{1}{c}{ \$millions) } & & & \\
\cline { 2 - 7 } & Curr Ops & Capital & Total & Curr Ops & Capital & Total \\
\hline Total Giving & $\mathbf{\$ 5 , 1 0 7 . 5}$ & $\mathbf{\$ 4 , 0 1 6 . 1}$ & $\mathbf{\$ 9 , 1 2 3 . 6}$ & $\mathbf{\$ 1 4 , 3 6 9 . 4}$ & $\mathbf{\$ 1 0 , 4 5 0 . 3}$ & $\mathbf{\$ 2 4 , 8 1 9 . 7}$ \\
\hline Control & & & & & & \\
Public & $2,407.7$ & $1,446.7$ & $3,854.4$ & $8,186.4$ & $4,576.3$ & $12,762.7$ \\
Private & $2,699.9$ & $2,569.3$ & $5,269.2$ & $6,183.0$ & $5,874.0$ & $12,057.0$ \\
\hline Carnegie Category & & & & & & \\
Multicampus & 773.5 & 403.5 & $1,177.0$ & $2,644.3$ & $1,240.9$ & $3,885.2$ \\
Doctoral & $3,146.0$ & $2,379.4$ & $5,525.5$ & $9,432.1$ & $6,658.5$ & $16,090.6$ \\
Master's & 292.9 & 310.7 & 603.7 & 562.1 & 640.6 & $1,202.7$ \\
Baccalaureate & 661.3 & 774.4 & $1,435.7$ & 956.8 & $1,404.1$ & $2,361.0$ \\
Special Focus & 231.5 & 146.6 & 378.0 & 761.0 & 501.6 & $1,262.5$ \\
4-Year & & & & & & \\
Associates & 2.3 & 1.4 & 3.8 & 13.1 & 4.5 & 17.6 \\
\hline
\end{tabular}

Gift Purpose by Institutional Control

Public institutions consistently received more of their gifts for current operations (62.5\% in 1988 and $64.1 \%$ in 2018) than private institutions (51.2\% in 1988 and $51.3 \%$ in 2018) (Figure 10). It follows that for private institutions endowment funding typically constitutes about half of their donated dollars. It is possible that private institutions more effectively communicate the need for long-term support due to their lack of state-appropriations and are more practiced at building long-term relationships that generate the biggest endowed gifts (Conley \& Tempel, 2006). It is also possible that donors may accept the importance of endowments at private institutions but feel more hesitant about the need and management of these funds in public universities. Baccalaureate institutions (which are mostly private) received a larger proportion of their funds for capital/ endowment $(53.9 \%-59.5 \%)$ than all other institutions types followed by master's institutions (51.5\%-53.3\%) and doctoral universities (43.1\%-41.4\%). Large multicampus institutions which are all public, skewed more toward current operations (65.7\%-68.1\%). Baccalaureate, master's, and special focus institutions received less of their funding for current operations in 2018 than 1988. 
Donor Type by Institutional Control

Philanthropic support from donors varies by institutional type, with private institutions generally receiving more of their dollars from individuals and public institutions receiving more organizational dollars (see Table 7 and Figure 11). Still for both public and private institutions a smaller proportion of dollars came from individuals in 2018 (37.5\% and 52.1\%) than in 1988 (39.6\% and 55.8\%). Private institutions have long been recognized as being more adept at building a culture of philanthropy among their students, which translated into higher proportions of giving among alumni (Conley \& Tempel, 2006) and is likely evident in the trends. Still, they too have shifted slightly toward organizational donors over time, perhaps as more individual high-wealth donors began using foundations and donor-advised funds for their giving. Researchers have also found that large-scale foundation giving tends to prioritize highly selective, research-oriented institutions (McClure, Frierson, Hall \& Ostlund, 2017) and that regional public universities (i.e., master's institutions) are not as adept yet at fundraising from individuals but especially organizations (McClure \& Anderson, 2020).

By General Purpose (Current Operations and Capital)
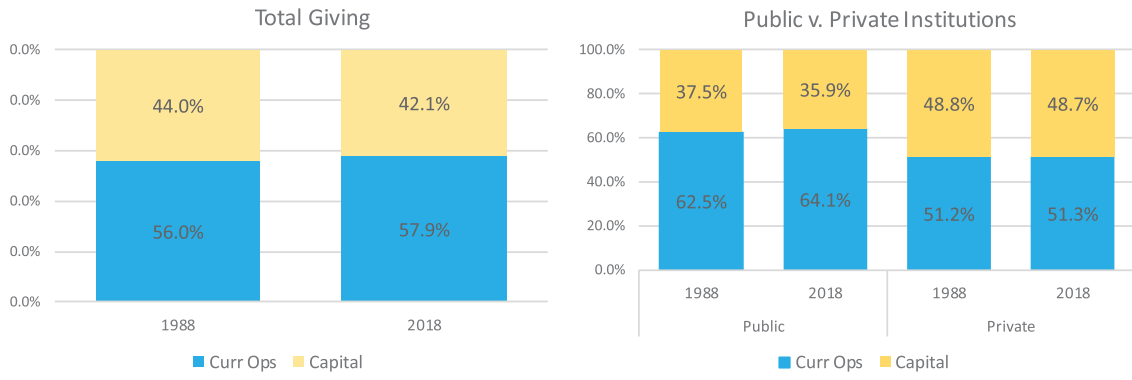

By Carnegie Category

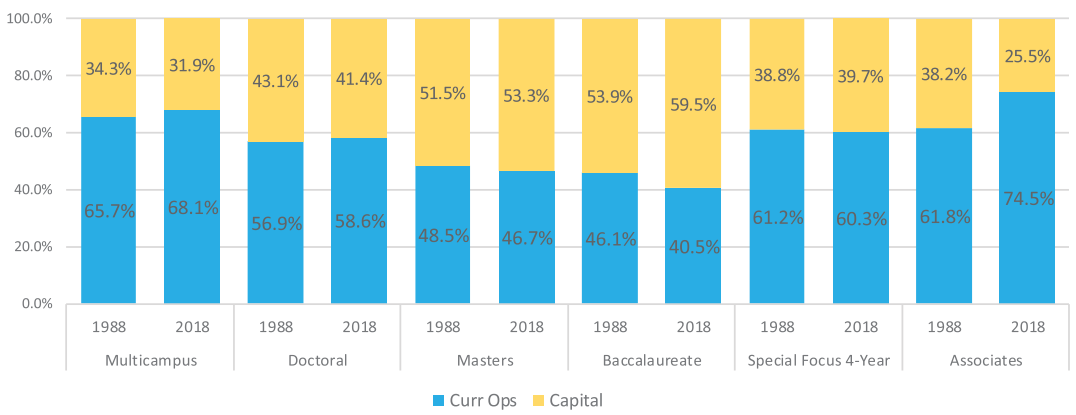

Figure 10. Changes in giving for current operations v. capital purposes by institutional control and Carnegie category. 
Table 7. Individual v. Organizational Donations by Institutional Control and Carnegie Category: Changes between 1988 and 2018

\begin{tabular}{lrr|rr}
\hline & \multicolumn{2}{c|}{$\mathbf{1 9 8 8} \mathbf{2 0 1 8 \text { millions }}$} & \multicolumn{2}{c}{$\mathbf{2 0 1 8}$ (\$ millions) } \\
\cline { 2 - 5 } & Individuals & Organizations & Individuals & Organizations \\
\hline Total Giving & $\mathbf{\$ 4 , 4 6 3 . 6}$ & $\mathbf{\$ 4 , 6 6 0 . 0}$ & $\mathbf{\$ 1 1 , 2 1 0 . 3}$ & $\mathbf{\$ 1 3 , 8 9 2 . 4}$ \\
Control & & & & \\
$\quad$ Public & $1,524.9$ & $2,329.5$ & $4,826.4$ & $8,031.4$ \\
Private & $2,938.7$ & $2,330.5$ & $6,383.9$ & $5,861.0$ \\
\hline Carnegie Category & & & & \\
Multicampus & 460.2 & 716.8 & $1,257.7$ & $2,659.9$ \\
Doctoral & $2,614.8$ & $2,910.6$ & $7,303.1$ & $8,958.4$ \\
Masters & 347.5 & 256.2 & 732.5 & 478.0 \\
Baccalaureate & 968.6 & 467.1 & $1,535.7$ & 891.7 \\
Special Focus 4-Year & 71.5 & 306.5 & 375.3 & 891.6 \\
Associates & 1.0 & 2.7 & 6.0 & 12.7 \\
\hline
\end{tabular}

By Donor Type (Individuals and Organizations)
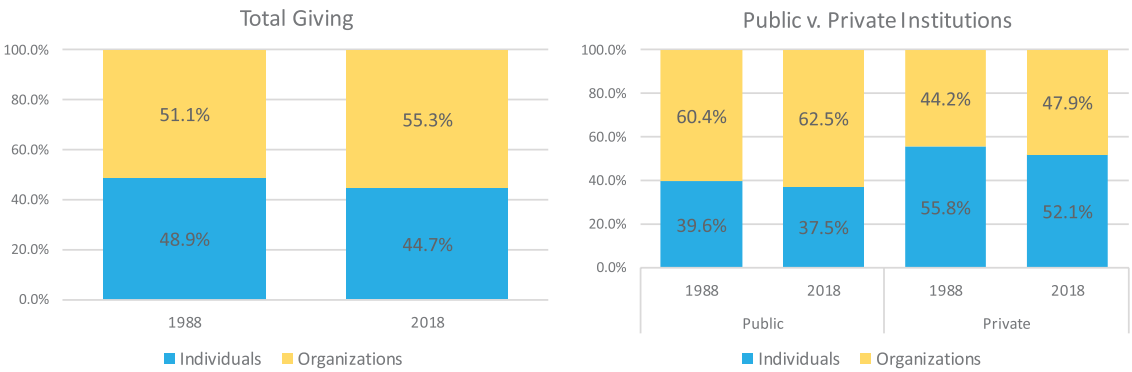

By Carnegie Category

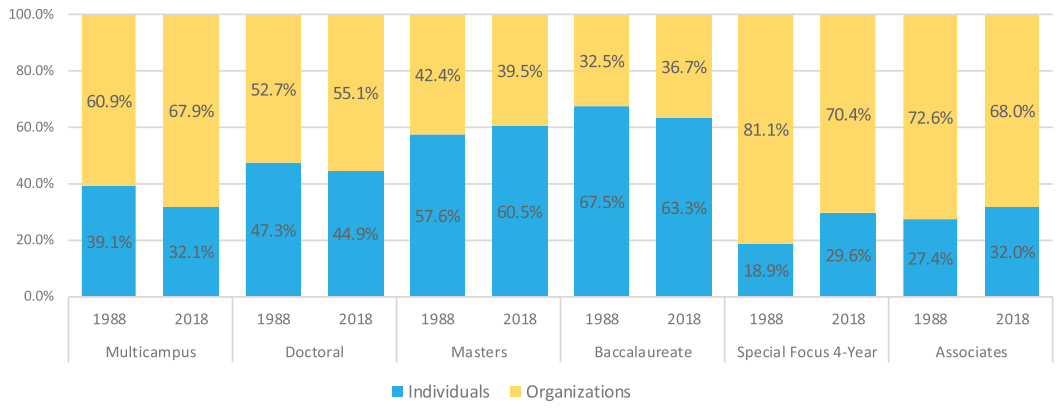

Figure 11. Changes in giving by individuals v. organizations by institutional control and Carnegie category. 


\section{LIMITATIONS}

It is worth noting that the VSE respondent population represents more traditional and historically stable institutions within the U.S. higher education landscape. This may make the study results more positive and optimistic than may be the prognosis or trajectory of other institutions with more emergent fundraising efforts and different alumni profiles. We cannot comment on whether higher education is seeing the decline in the number of donors and relying more heavily on big donors, that is concerning the nonprofit world generally (Grimm \& Dietz, 2018; Rooney, 2018). Still, the increase in giving is notable and promising as other institutions continue to intensify their fundraising programs; and higher education fundraisers are acutely aware of the need to focus on their pipeline of small gifts and new donors.

This analysis is descriptive but does not explain why the trends occurred. A limitation, or perhaps a more general issue regarding empirical research in this area, is the population reference for generalization. As we noted in the beginning of the "Findings and Interpretation" section, our panel sample includes a larger proportion of public institutions compared to the full VSE respondent population. However, neither our sample nor the VSE reflect the higher education landscape, for example, in terms of the number of private institutions or associate's/community colleges. In addition, our current operations focus and timeframe meant we did not delve deeply into the restricted endowment category, which was not broken down further in the survey until 1993. Still, our panel sample captures twothirds of all the donations recorded in the VSE and our results align well with the full survey's donor and purposes breakdowns, suggesting that this longitudinal approach was a suitable variation on the VSE's cross-sectional reporting strategy.

\section{DISCUSSION}

Much interpretation is provided in the findings section, thus this section is guided by the highest level trends from the analysis, as illustrated by Figure 12. The figure highlights the overall growth, with the largest 10 -year increase between 1988 and 1998 before stabilizing at a lower level over the next two decades. Figure 12 also shows the shifts toward organizational over individual donors, current operations over capital/endowment donations, donations for restricted as compared to unrestricted purposes, and public institutions catching up to and surpassing the private institutions in this panel sample. The disaggregation of each trend across the public and private (non-profit) sectors also reveals the inter-relationships among these trends. Specifically, the change toward individual donors is primarily a private sector trend exacerbated by the shift toward higher support for the public institutions. The more recent trend toward giving for current operations (from 1998 to 2018) is similarly exacerbated by the shift in support by sector, after both sectors experienced the reverse trend (toward capital/endowment giving) between 1988 and 1998. The general trend toward giving for current 


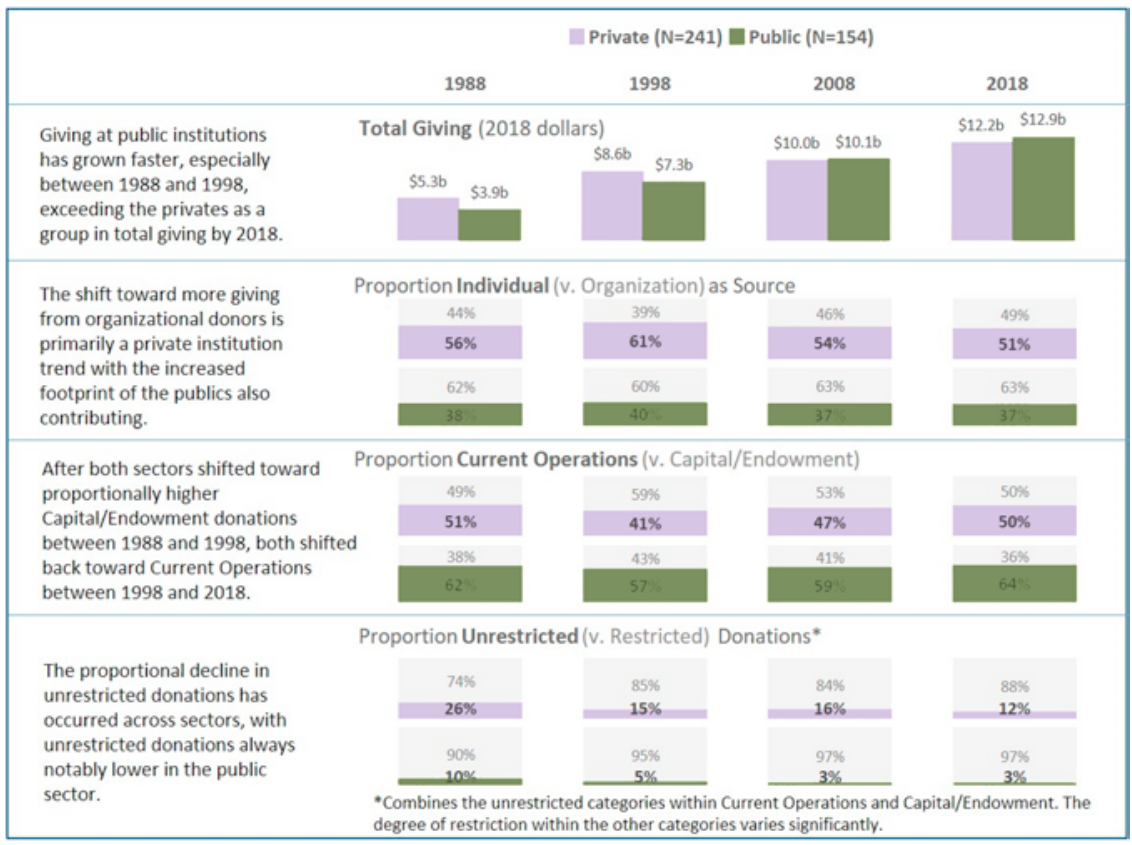

Figure 12. Summary of major trends for private and public institutions regarding overall giving, donor types, and gift purposes

operations is also largely due to the increased footprint of the public institutions in this sample. Both sectors showed a similar pattern with an early shift (1988 to 1998) toward capital/endowment funding, and then the private sector returned to its 1988 level by 2018. The public sector shifted back to and then past its original levels toward a higher proportion of funding for current operations (64\%) by 2018.

By disaggregating the trends among public and private institutions, we see that the trend toward organizational giving was especially true for private institutions. Far from lessening, within the bounds of this study, foundations dedicated additional philanthropic efforts to higher education contributions (Bernstein, 2014; Hall, 2011). Institutions should pay careful attention to understanding their mix of foundation donors and to building teams and programs aimed at working with these donors. Corporate philanthropy had a slower growth rate during this study period and fell behind the other donor types. Looking ahead, higher education leaders need to be very tactical in crafting and presenting projects to corporations that clearly fit with corporate strategy (Clevenger, 2014).

At the same time, institutions must continue to nurture their individual giving programs. Alumni consistently gave at least one-quarter of the philanthropic dollars. Cultivating alumni support at colleges and universities of all kinds, and especially public ones, is a recognized priority and known challenge in the press to improve or at least keep the status quo (Conley \& Tempel, 2006). Other individuals increased their giving during the study but more slowly than the overall 
rate of increase. This suggests that institutions need to actively show other, nonalumni donors why they should give and consider developing specific fundraising strategies and projects for this audience.

A closer look at current operations compared to capital/endowment purposes shows that this was primarily a public sector trend. In private institutions the distribution was more proportional, though 1998 showed a notable decline in current operations funding for both types before a rebound by 2018. As articulated previously, it is possible that donor sentiment regarding perpetual gifts (i.e., capital/endowment) is different for private versus public institutions, where they might expect such long-term and ongoing needs to be met by government funding. Additionally, the press for public accountability and especially achievement gaps by race/ethnicity and socioeconomic status, led to a rise in the role of nonprofits, foundations, and association as advocates for and direct funders of initiatives, primarily at public institutions, to improve success rates among traditionally underserved populations (Ewell, 2008; Ostrander, 2007). This is sign that the needs of public and private institutions can differ-and this can certainly be reflected in how they seek philanthropic gifts and for what purpose (Conley \& Tempel, 2006).

Also related to the purposes of donors' gifts, the study shows the designation of a larger proportion of funds for restricted, rather than unrestricted purposes in both broad categories of giving and for public and private institutions alike. Since the beginning of US higher education, donors have given for restricted and specific purposes (Drezner, 2011; Thelin \& Trollinger, 2014). Donors increasingly exhibited this preference in a conspicuous way across the three decades of this study. A caveat is that donors were quite supportive of academic divisions (i.e., academic schools, departments, programs), which allowed for "unrestricted" gift use within specified units. Donors are thought to be increasingly engaged and involved before and after gifts are made (Drezner, 2011), which may relate to the trend toward restricted giving. Student aid funding received a declining proportion of support and was not among the largest of the current operations restricted purposes, which was unexpected and not easily explained given widespread attention to rising college costs (Ma, et al., 2018; Mitchell et al., 2016; Webber, 2017). More information is needed to examine restricted endowment giving and institutional financial aid practices. It is still worth mentioning in the context that institutions play influential roles in communicating their priorities to donors and seeking gifts for specific purposes. If institutions want more student aid funding or unrestricted funding (or capital/endowment funding, for that matter), continued and careful efforts are needed to educate donors about particular needs and be transparent when the funds are used.

Finally, the longitudinal data show a higher proportion of dollars going to public, rather than private institutions. With an average annual growth rate of $4.3 \%$, public institutions moved from raising $27 \%$ less than privates to generating 5\% more. Public institutions should be hopeful regarding this development. Private institutions still raise more money than ever before, but their growth rate 
has been slower than for public institutions. The next ten years will be telling for both public and private institutions to see whether rates of growth can be maintained particularly considering changes in tax incentives and public opinion about higher education (including its politicization) (Brown, 2018). Both public and private institutions need to maintain (or increase) their investments in fundraising and explore innovative technologies to resonate with different donor populations.

There is ample opportunity to extend the research about higher education philanthropy using other data sets and methods to, for example, complete further quantitative analysis within the VSE donor types and gift purposes categories, undertake qualitative assessments of donors' goals and rationales, and assemble institutional-level historical trend analysis and projections. The research on organizational and non-alumni individual support for higher education remains underdeveloped but particularly important as evidenced by the changing proportions of giving shown in this study. Researchers could also study the institutions' roles in directing donor gifts to various purposes (i.e., current operations vs capital/ endowments, student financial aid vs other restricted purposes) and how fundraising efforts, staffing, and programs have evolved at institutions of different kinds. Another opportunity lies in trying to better understand relationships between public opinion, social phenomenon, and giving to higher education. As the biggest donors are thought to be influencing higher education, more information is needed about their involvement and the institutional and sectoral outcomes on higher education.

While there is certainly a need for more knowledge, this research is a tool for post-secondary leaders to use in benchmarking and strategic fundraising planning in relation to important, long-term trends. College and university leaders can also use data to adapt fundraising efforts, programs, and priorities to meet donor preferences and expectations. Institutions also need to foreground mission-driven, strategic needs, and priorities in their donor communications and to educate the public generally about the role that philanthropy plays in higher education.

\section{CONCLUDING THOUGHTS}

Philanthropic support for higher education over the past three decades has been strong. This study showed that donors give more to higher education now than they did 30 years ago, while noting distinct changes in the manifestation of that support over time. Higher education, however, may be at a turning point, despite investments and increased sophistication in fundraising (Gardner, 2017, 2018; Ruffalo Noel Levitz, 2018). This may come as a result of the documented decline in the number of Americans making philanthropic contributions (Grimm \& Dietz, 2018; Rooney, 2018); changing tax policy (Delaney \& Thompson, 2019; Rooney, 2018); and higher education conditions such as struggles in alumni association relevance, new giving patterns among millennials, and lagging efforts to appeal to diverse donors (Drezner, 2013; O'Neil, 2014). Indeed, declines in higher education giving were already predicted for 2019 and have been extended 
for 2020 due to the coronavirus (Bauer-Wolf, 2020; Paterson, 2019). Together, the coronavirus and wide-spread protests of systemic racism have upended society, including the functioning of colleges and universities and lives of their students, employees, and donors. The coronavirus caused many institutions to halt and then redirect fundraising efforts to focus on the needs of students and have called into question much about the future of individual institutions and the sector (Scutari, 2020). In response to the virus and pressing need for social equity, organizational donors are reevaluating their giving criteria and strategies and individual donors may also respond by giving in new ways (Blumenstyk, 2020; Scutari, 2020; Stewart \& Kulish, 2020). University advancement leaders do not expect to meet their fundraising goals this year and anticipate a years' long decline in giving (Haynes, 2020).

All told, the present circumstances likely will not only affect the amount of money donated to higher education, but also its distribution by donor type, purpose, and institution. In positive terms, there may be opportunities for institutions and donors to collaborate in new ways to serve students and society (Scutari, 2020). Less optimistically, 2020 events could dramatically lessen or redistribute funding that institutions rely on for all matter of purposes (Haynes, 2020; BauerWolf, 2020). The future trajectory of higher education philanthropy may be very different than what has come before-subsequent analyses will be needed to track and understand those changes.

\section{ACKNOWLEDGEMENT}

This research was supported by funding from the TIAA Institute. The content, findings, and conclusions are the responsibility of the authors and do not necessarily represent the view of TIAA or the TIAA Institute. Our thanks to the Institute and to Indiana University graduate students Pat Danahey Janin and $\mathrm{Yu} \mathrm{Hu}$ for their meaningful contributions to this project.

\section{APPENDIX A}

This study is based on responses from the VSE survey. The VSE survey provides institutional level data regarding donor type and donation purpose. The definitions of donor type and donation purpose are provided in the following Appendix Tables $1 \mathrm{~A}$ and $2 \mathrm{~A}$.

Appendix Table 1A provides the definitions of donor types. We divide the donors into five types; the first two represent individuals (alumni, all other individuals) and the remaining three are organizations (foundations, corporations, all other organizations). 
Appendix Table 1A. Definitions of Donor Types

\begin{tabular}{cl}
\hline $\begin{array}{l}\text { Donor Type } \\
\text { Individual }\end{array}$ & Definition \\
Alumni & $\begin{array}{l}\text { All former students at all levels who have earned some credit } \\
\text { towards something (i.e., completed at least one course with } \\
\text { passing grades) } \\
\text { Other individuals } \\
\text { Includes all non-alumni individuals, including parents, } \\
\text { grandparents, and other individuals * }\end{array}$ \\
Foundations & $\begin{array}{l}\text { Personal and family foundations, community foundations, } \\
\text { private tax-exempt entities } \\
\text { Forporations }\end{array}$ \\
$\begin{array}{l}\text { For-profit corporations, partnerships, cooperatives, includ- } \\
\text { ing closely held companies. Includes company foundations, } \\
\text { trade associations } \\
\text { Oncludes religious organizations, fundraising consortia (i.e., }\end{array}$ \\
$\begin{array}{l}\text { United Negro College Fund, United Way), and other orga- } \\
\text { nizations * }\end{array}$ \\
\hline
\end{tabular}

Source: CASE (2018).

*In the VSE, these donor types appear as separate groups. Because these are relatively small groups, for the purpose of this analysis, we grouped them together into pooled categories.

\section{APPENDIX A-CONTINUED}

Appendix Table 2A provides the definitions of the two broad purposes of gifts, which are first categorized as current operations and capital/endowment. Current operations gifts are either unrestricted or restricted to specific purposes, resulting in nine distinct sub-categories. Capital/endowment is divided into four sub-purposes, both restricted and unrestricted.

Appendix Table 2A. Definitions of Donation Purposes

\begin{tabular}{ll}
\hline Outright Gifts & Definition \\
\hline $\begin{array}{l}\text { Current Operations } \\
\text { Unrestricted }\end{array}$ & $\begin{array}{l}\text { No restriction at all } \\
\text { Academic divisions }\end{array}$ \\
$\begin{array}{l}\text { Restricted only to particular academic divisions, no fur- } \\
\text { ther restriction }\end{array}$ \\
Faculty and staff & $\begin{array}{l}\text { Restricted to faculty and staff salaries and employment } \\
\text { benefits }\end{array}$ \\
Research & Restricted private grants for scientific, technical, and \\
& humanistic investigations (excluding clinical trials) \\
\hline
\end{tabular}

(Continued) 
Appendix Table 2A. Continued.

Public service and extension

Library

Physical plant

Student aid

Athletics

Other

\section{Capital/endowment}

Property, buildings, equipment

Unrestricted endowment

Restricted endowment

Loan funds
Restricted to non-instructional services for people and groups within or outside the institution (i.e., support activities primarily for radio/tv stations, community service)

Restricted for materials and activities appropriate to a library

Restricted to ongoing operations of building, grounds, facilities, equipment

Restricted to financial aid for students, need- and meritbased, awards, etc.

Restricted to athletic department, intramural and extramural activities

Restricted to specific uses not classified otherwise such as auxiliary, hospitals, non-academic units

Outright gifts of personal property for physical use, gifts for purchasing buildings or land, gifts for construction or renovation, gifts to retire debt

Donor restricts money to be held in an endowment but doesn't restrict use of income

Donor restricts money to be in endowment and limits use of income to particular purposes.

Restricted by donors for loans to students, faculty, and staff

Source: CASE (2018).

\section{Notes}

1. Percentages derived from NCES IPEDS Data Center, selecting all U.S. based Title IV, degree granting institutions and their proportion of 2017-18 revenues from "private gifts, grants, and contracts as a percent of core revenues" reported through both the GASB and FASB forms. All 1,664 private, non-profit institutions report using the FASB form. The vast majority $(1,642)$ of public institutions report using GASB with a small number (50) reporting using the FASB form. The public percentage was derived using a weighted average of the GASB and FASB reported results.

2. An estimation process based on percentage change of participants and Carnegie classification of non-participants is used to derive a national estimate (CASE, 2019a). The numbers reported in this study do not include this estimation and, therefore, vary from public reporting about the VSE.

3. For the remaining analysis, inflation-adjusted dollar values are discussed. 


\section{References}

Andreoni,J. (1990). Impure altruism and donations to public goods: A theory of warm-glow giving. The Economic Journal, 100(401), 464-477.

Arnim, E. (2019, October 16). How community colleges attract major gifts. EAB Daily briefing. Retrieved from https://eab.com/research-and-insights/

Bacchetti, R., \& Ehrlich, T. (2007). Reconnecting education and foundations:Turning good intentions into educational capital. San Francisco, CA: Jossey-Bass.

Bauer-Wolf, J. (2020, April 21). College fundraisers fear they won't meet goals because of coronavirus, survey says. Education Dive. Retrieved from https://www.educationdive.com/

Bernstein, A. R. (2014). Funding the future: Philanthropy's influence on American higher education. Lanham, MD: Rowman \& Littlefield Education.

Blackbaud. (2018). 2017 donorCentics annual report on higher education giving. Available from https:// www.blackbaud.com

Bloomberg, M. R. (2018, November 23). Why I'm giving $\$ 1.8$ billion for college financial aid. The New York Times. Retrieved from https://www.nytimes.com

Blumenstyk, G. (2020, April 1). How the coronavirus is prompting higher-ed grantmakers to change course. The Chronicle of Higher Education. Retrieved from https://www.chronicle.com

Brown, A. (2018, July 26). Most see higher ed going the wrong direction. Partisans split on why. Pew Research Center. Retrieved from https://www.pewresearch.org/fact-tank/2018/07/26/most -americans-say-higher-ed-is-heading-in-wrong-direction-but-partisans-disagree-on-why/

Brown, J. R., Dimmock, S. G., Kang, J. K., \& Weisbenner, S. J. (2014). How university endowments respond to financial market shocks: evidence and implications. American Economic Review, 104(3), 931-62.

Caboni, T. C. (2010). The normative structure of college and university fundraising behaviors. The Journal of Higher Education, 81(3), 339-365.

Cascione, G. L. (2003). Philanthropists in higher education: Institutional, biographical, and religious motivations for giving. New York \& London: RoutledgeFalmer.

Cheslock, J. J., \& Gianneschi, M. (2008). Replacing state appropriations with alternative revenue sources: the case of voluntary support. The Journal of Higher Education, 79(2), 208-229.

Clevenger, M. R. (2014). An organizational analysis of the inter-organizational relationships between a public American bigher education university and six United States corporate supporters: An instrumental, ethnographic case study using Cone's corporate citizenship spectrum (Doctoral Dissertation). Retrieved from https://hdl.handle.net/10355/45866

Clotfelter, C. T. (2003). Alumni giving to elite private colleges and universities. Economics of Education Review, 22(2), 109-120.

Conley, A., \& Tempel, E. R. (2006). Philanthropy. In D. M. Priest \& E. P. St.John (Eds.). Privatization and public universities (pp 151-172). Bloomington, IN: Indiana University Press.

Council for Advancement and Support of Education (CASE). (2018). Voluntary support of education. reporting standards and management guidelines (4th Ed.). [Not publicly available]. Access granted by CASE.

Council for Advancement and Support of Education (CASE). (2019a, February). 2018 Voluntary support of education. (Research brief). Retrieved from https://www.case.org/resources/2018 -voluntary-support-education 
Council for Advancement and Support of Education (CASE). (2019b, February). 2018 Voluntary support of education. Trends in alumni giving. Retrieved from https://www.case.org/resources /voluntary-support-education-trends-alumni-giving

Council for Advancement and Support of Education (CASE). (2020, February). Voluntary support of education key findings, 2018-2019. Retrieved from https:/www.case.org/resources /voluntary-support-education-key-findings-2018-19

Cunningham, B. M. \& Cochi-Ficano, C. K. (2002). The determinants of donative revenue flows from alumni of higher education: An empirical inquiry. The Journal of Human Resources, 37(3), 540-569.

Delaney, T., \& Thompson, D. (2019, January 14). The effects of 2019 tax-policy decisions will linger for decades. It's time to weigh in. The Chronicle of Philanthropy. Retrieved from https://www .philanthropy.com/

Drezner, N. D. (2006). Recessions and tax-cuts: Economic cycles' impact on individual giving, philanthropy, and higher education. International Journal of Educational Advancement, 6(4), 289-305.

Drezner, N. D. (2011). Philanthropy and fundraising in American higher education, San Francisco., CA: Jossey-Bass.

Drezner, N. D. (Ed.). (2013). Expanding the donor base in higher education: Engaging non-traditional donors. New York, NY: Routledge.

Drezner, N. D., \& Huehls, F. (2014). Fundraising and institutional advancement: Theory, practice, and new paradigms. New York, NY and Oxfordshire, England: Routledge.

Drezner, N., Pizmony-Levy, O., \& Pallas, A. M. (2018). Americans' views of higher education as a public and private good.1-16. https://doi.org/10.7916/D8V7129F

Duronio, M. A., \& Loessin, B. A. (1990). Fund-raising outcomes and institutional characteristics in ten types of higher education institutions. The Review of Higher Education, 13(4), 539-556.

Ehrenberg, R. G., \& Smith, C. L. (2003). The sources and uses of annual giving at selective private research universities and liberal arts colleges. Economics of Education Review, 2(3), 223-235.

Ewell, P. (2008). Assessment and accountability in America today: Background and context. In V. Borden \& G. Pike (Eds.). New Directions for Institutional Research, 2008(S1), 7-17.

Field, K. M. (2011). Engaging institutional environments and alumni donor participation rates: Is there a linkage? (Doctoral dissertation). Florida State University.

Foster, W. (2016, April 27). Why big donors are under fire for big gifts. Forbes. Retrieved from http:// www.forbes.com

Foundation Center. (2019). Foundation Stats. Retrieved from http://data.foundationcenter.org /\#/foundations/all/nationwide/total/list/2015

Frank, K. A. (2014). Twenty-five years of giving: Using a national data set to examine private support for higher education. (Doctoral dissertation). University of Southern Florida.

Frumkin, P., \& Kaplan, G. (2010). Foundations and higher education. In H. K. Anheier \& D. C. Hammack (Eds.). American foundations: Roles and contributions (pp. 98-119). Washington, D.C.: Brookings Institution Press.

Fukui, F. (2020). Do government appropriations and tax policies impact donations to public research universities in Japan and the USA? Higher Education. https://doi.org/10.1007/s10734-020-00543-0

Gardner, L. (2017, December 15). Public universities are getting better at bagging big gifts. The Chronicle of Higher Education. Retrieved from https://www.chronicle.com

Gardner, L. (2018, September 16). In the drive for donors, regional public colleges have a lot of catching up to do. The Chronicle of Higher Education. Retrieved from https://www.chronicle.com 
Gearhart, G. D., \& Miller, M. T. (2018). Perspectives on time commitment to fundraising by community college presidents. Journal of Research on the College President, 2(1). Retrieved from https:// scholarworks.uark.edu/jrcp/vol2/iss1/7

Giving USA Foundation (2019). Giving USA 2019. Chicago, IL: Giving USA Foundation.

Gottfried, M. A., \& Johnson, E. L. (2006). Solicitation and donation: an econometric evaluation of alumni generosity in higher education. International Journal of Educational Advancement, 6(4), 268-281.

Grant, J. H., \& Lindauer, D. L. (1986). The economics of charity life-cycle patterns of alumnae contributions. Eastern Economic Journal, 12(2), 129-141.

Grimm, R.T.,Jr., \& Dietz, N. (2018). “Where are America’s volunteers? A look at America's widespread decline in volunteering in cities and states." (Research Brief). College Park, MD: Do Good Institute, University of Maryland. Retrieved from https://publicpolicy.umd.edu/

Gunsalus, R. (2005). The relationship of institutional characteristics and giving participation rates of alumni. International Journal of Educational Advancement, 5(2), 162-170.

Haddad, N., \& Reckhow, S. (2018). The shifting role of higher education philanthropy: a network analysis of philanthropic policy strategies. Philanthropy $\mathcal{E}^{2}$ Education, 2(1), 25-52.

Hall, C. E. (2011). 'Advocacy philanthropy' and the public policy agenda: the role of modern foundations in American higher education (Master's thesis). The Claremont Graduate University. Retrieved from https://search.proquest.com/pqdtglobal/docview/901126299/abstract /505931A57DCE4E8BPQ/1

Harris, J.T. (1990). Private support for public doctoral-granting universities: Building a theoretical base. The Review of Higher Education, 13(4), 519-538.

Harrison, W. B. (1995). College relations and fund-raising expenditures: Influencing the probability of alumni giving to higher education. Economics of Education Review, 14(1), 73-84.

Harrison, W. B., Mitchell, S. K., \& Peterson, S. P. (1995). Alumni donations and colleges' development expenditures: Does spending matter? American Journal of Economics and Sociology, 54(4), 397-412.

Haynes, E. (2020, June 8). College fundraising expected to drop sharply in the next few years. The Chronicle of Philanthropy. Retrived from https://www.philanthropy.com

Hunt, J. (2018). University of Nike: How corporate cash bought American higher education. New York and U.K.: Melville House Publishing.

Indiana University Center for Postsecondary Research (2019). 2018 update facts and figures: Decriptive highlights. Carnegie Classification of Institutions of Higher Education. Retrieved from https:// carnegieclassifications.iu.edu/downloads/CCIHE2018-FactsFigures.pdf

Indiana University Lilly Family School of Philanthropy. (2013). A decade of million-dollar gifts: A closer look at major gifts by type of recipient organization, 2000-2011. Indianapolis, IN. Retrieved from https://scholarworks.iupui.edu/handle/1805/5744

Jaschik, S. (2017, February 22). Malcolm Gladwell vs Stanford fund-raising. Inside Higher Ed. Retrieved from https://www.insidehighered.com

Kelly, A. P., \& James, K. J. (2015). Is the 'new' education philanthropy good for schools? Examining foundation-funded school reform. Presented at American Enterprise Institute, Washington, DC.

Kim, A. (2017, October 4). The bipartisan quest for college-endowment reform. The Atlantic. Retrieved from https://www.theatlantic.com

Kroll, J. A. (2012). Benchmarking investments in advancement: Results of the inaugural CASE Advancement Investment Metrics Study (AIMS). CASE White Paper. Council for Advancement and Support of Education. 
Lara, C., \& Johnson, D. (2014). The anatomy of a likely donor: Econometric evidence on philanthropy to higher education. Education Economics, 22(3), 293-304.

Leslie, L. L., Drachman, S. S., Conrad, C. F., \& Ramey, G. W. (1983). Factors accounting for variations over time in voluntary support for colleges and universities. Journal of Education Finance, 9(2), 213-225.

Leslie, L. L., \& Ramey, G. (1988). Donor behavior and voluntary support for higher education institutions. The Journal of Higher Education, 59(2), 115-132.

Lorin, J. (2017, December 26). University endowments. Bloomberg QuickTake. Available from https:// www.bloomberg.com/quicktake/university-endowments

Lu, J. (2016). The philanthropic consequence of government grants to nonprofit organizations: A meta-analysis. Nonprofit Management and Leadership, 26(4), 381-400.

Ma, J., Baum, S., Pender, M., \& Libassi, C. (2018). Trends in college pricing 2018. New York, NY: The College Board.

Mael, F., \& Ashforth, B. E. (1992). Alumni and their alma mater: a partial test of the reformulated model of organizational identification. Journal of Organizational Behavior, 13(2), 103-123.

McClure, K. R., \& Anderson, P. N. E. (2020). An uneven playing field: Fundraising at regional public universities in the aftermath of the great recession. Philanthropy Eं Education, 3(2), 1-26.

McClure, K. R., Frierson, L., Hall, A. W., \& Ostlund, K. L. (2017). Philanthropic giving by foundations to higher education institutions: a state-level social network analysis. Philanthropy E Education, 1(1), 1-28.

McClure, K. R., \& Titus, M. A. (2018). Spending up the ranks? The relationship between striving for prestige and administrative expenditures at US public research universities. The Journal of Higher Education, 89(6), 961-987.

Mitchell, M., Leachman, M., \& Masterson, K. (2016, August 15). Funding down, tuition up: State cuts to higher education threaten quality and affordability of public colleges. Washington, DC: Center on Budget and Policy Priorities. Retrieved from https://www.cbpp.org/research/state -budget-and-tax/funding-downtuition-up

Muller, T. E., \& Sepehri, V. A. (1988). Corporate support of higher education: trends in Canada and the United States. Research in Higher Education, 28(2), 160-179.

Nyman, J., Pilbeam, C., Baines, P., \& Maklan, S. (2018). Identifying the roles of university fundraisers in securing transformational gifts: Lessons from Canada. Studies in Higher Education, 43(7), 1227-1240.

O'Neil, M. (2014, September 8). From millennial donors, little loyalty to alma mater. The Chronicle of Higher Education. Retrieved from https://www.chronicle.com

Ostrander, S. A. (2007). Innovation, accountability, and independence at three private foundations funding higher education civic engagement, 1995 to 2005. Nonprofit Management and Leadership, 18(2), 237-253.

Oxtoby, D. (2015, September 21). Endowments are financial pillars, not piggy banks. The Chronicle of Higher Education. Available from https://www.chronicle.com

Paterson, J. (2019, February 19). Giving to higher ed will slow in 2019, Moody's predicts. Education Dive. Available from https://www.educationdive.com/

Proper, E., \& Caboni, T. (2014). Institutional advancement: What we know. New York, NY: Springer.

Proper, E., Caboni, T. C., Hartley, H. V., \&Willmer, W. K. (2009). “More bang for the buck”: Examining influencers of fundraising efficiency and total dollars raised. International Journal of Educational Advancement, 9(1), 35-41. http://dx.doi.org/10.1057/ijea.2009.19 
Rockefeller Philanthropy Advisors \& TIAA Institute. (2017). Achieving success in postsecondary education: Trends in philanthropy. New York, NY:TIAA. Retrieved from https:/www.tiaainstitute.org/

Rooney, P. (2018, February 1). Charity and taxes: 4 questions answered. The Conversation. Retrieved from https://theconversation.com/

Ruffalo Noel Levitz. (2018). Advancement leaders speak 2018: The future of higher education fundraising campaigns. Cedar Rapids, IA: Ruffalo Noel Levitz.

Satija, N. (2018, January/February/March). How rich universities waste their endowments. Washington Monthly. Available from https://washingtonmonthly.com

Scutari, M. (2018a, October 25). It was a very good year: How did a regional public university make fundraising history? Inside Philanthropy. Retrieved from https://www.insidephilanthropy.com

Scutari, M. (2018b, August 24). Mega-gifts are rising and alumni giving is shrinking. Which means what, exactly? Inside Philanthropy. Retrieved from https://www.insidephilanthropy.com

Scutari, M. (2018c, December 18). Mega-donors rarely support historically black colleges. Will this gift change that? Inside Philantbropy. Retrieved from https://www.insidephilanthropy.com

Scutari, M. (2019, February 11). A public university mega-gift raises questions concerning donor influence and equity. Inside Philanthropy. Retrieved from https://www.insidephilanthropy.com

Scutari, M. (2020, April 8). Course correction: Will the coronavirus crisis upend the higher ed fundraising model? Inside Philanthropy. Retrieved from https://www.insidephilanthropy.com

Seltzer, R. (2017, October 17). Aiming for billions. Inside Higher Ed. Retrieved from https://www .insidehighered.com

Seltzer, R. (2018a, January 25). Endowments rebound, but is it enough? Inside Higher Ed. Retrieved from https://www.insidehighered.com

Seltzer, R. (2018b, February 6). Giving to colleges rises by 6.3\%. Inside Higher Ed. Retrieved from https://www.insidehighered.com

Shaker, G. G., \& Borden, V. M. H. (2020, March). How donors give to higher education. Thirty years of supporting U.S. college and university missions. (Research report). Research Dialogue, No. 158. TIAA Institute. Available from https://www.tiaainstitute.org/

Simone, S. A. (2009). Examining the influence of selectivity on alumni giving at public universities: a dynamic panel modeling approach (Doctoral dissertation). Retrieved from the University of Maryland. Available from https://drum.lib.umd.edu/handle/1903/9928

Stewart, J. B., \& Kulish, N. (2020, June 10). Leading foundations pledge to give more, hoping to upend philanthropy. The New York Times. Retrieved from https://www.nytimes.com

Taylor, A. L., \& Martin,J. C, Jr. (1995). Characteristics of alumni donors and non-donors at a research I, public university. Research in Higher Education, 36(3), 283-302.

Terry, N., \& Macy, A. (2007). Determinants of alumni giving rates. Journal of Economics and Economic Education Research, 8(3), p. 3-18.

The Chronicle List. (2018, March 11). Characteristics of colleges that raised the most in private donations, FY 2017. The Chronicle of Higher Education. Retrieved from https://www.chronicle.com

The Chronicle of Higher Education. (2018, August 19). Almanac 2018. Average annual effective spending rates for U.S. college endowments, FY 2017. The Chronicle of Higher Education. Retrieved from https://www.chronicle.com

Thelin, J. R., \& Trollinger, R. W. (2014). Philanthropy and American higher education. New York, NY : Palgrave Macmillan 
Thompson, L. A. (2010). Data mining for higher education advancement: A study of eight North American colleges and universities (Doctoral dissertation). Retrieved from ProQuest Dissertations \& Theses database. (822168028)

Trow, M. A. (1993). The analysis of status. In B. Clark (Ed.), Perspectives on higher education: Eight disciplinary and comparative views (pp. 132-164). Berkeley, CA: University of California Press.

U.S. Department of Education (2018), National Center for Education Statistics (Ed.), Digest of Education Statistics. Retrieved from https://nces.ed.gov/programs/digest/d18/tables/dt18 _307.10.asp

Valbrun, M. (2018, December 11). Fund-raising amid scandal. Inside Higher Ed. Retrieved from https:// www.insidehighered.com

Van Fleet, J. W. (2010). Corporate giving to education during economic downturns: general trends and the difficulty of prediction. International Journal of Educational Advancement, 9(4), 234-250

Webber, D. A. (2017). State divestment and tuition at public universities. Economics of Education Review, 60,1-4. doi.org/10.1016/j.econedurev.2017.07.007

Weerts, D. J., \& Ronca, J. M. (2007). Profiles of supportive alumni: Donors, volunteers, and those who "do it all". International Journal of Educational Advancement, 7(1), 20-34.

Wheatley, S. C. (2010). The partnerships of foundations and research universities In H. Anheier, \& D. Hammack (Eds.). American foundations. Roles and contributions. (pp. 73-97) Washington, D.C.: Brookings.

Winston, G. C. (1999) Subsidies, hierarchy and peers: the awkward economics of higher education. Journal of Economic Perspectives, 13(1), 13-36. 